\begin{tabular}{|l|l|l|l|l|l|}
\hline MUNIBE Antropologia-Arkeologia & $n^{\circ} 72$ & $185-202$ & DONOSTIA & 2021 & ISSN 1132-2217 • eISSN 2172-4555 \\
\hline
\end{tabular}

\title{
Baserri-paisaiaren geoarkeologia Zizurkilen (Gipuzkoa): Erdi Arotik XXI. mendera
}

\author{
Geoarqueología del paisaje rural en torno a los caseríos \\ de Zizurkil (Gipuzkoa) de la Edad Media al siglo XXI \\ Geoarchaeology of the rural landscape in Zizurkil (Gipuzkoa, \\ Basque Country) from the Middle Ages to the $21^{\text {st }}$ century
}

\begin{abstract}
GAKO-HITZAK: Paisaia, baserria, laborantza, tokiko historia, lurzoruak.
PALABRAS CLAVES: Paisaje, caserío, agricultura, historia local, suelos.

KEY WORDS: Landscape, farmsteads, agriculture, local history, soils.
\end{abstract}

Josu NARBARTE ${ }^{(1,2) *}$, Oihane MENDIZABAL ${ }^{(1,3)}$, Eneko IRIARTE ${ }^{(1,4)}$

\section{LABURPENA}

Euskal Herriaren isurialde atlantiarreko landa-espazioaren okupazio eredu nagusia da baserria, sakabanatutako etxe-unitate autonomoz osatua. Azken hamarkadetan, baserriaren arkitektura ikuspegi arkeologiko batetik ikertu da, serie krono-tipologiko zehatzak definituz. Lan honetan, baserriak artikulatzen dituen paisaia kulturalak aztertzea proposatzen dugu, laborantzak utzitako arrasto materialak —esparru produktibo espezifikoen egokitzapena edota kudeaketa-praktika bereizgarriak, ongarritzea kasu— eraikinen bilakaerarekin alderatuz. Analisia Zizurkilgo kasuan zentratu da (Gipuzkoa). Iturri dokumentalen, ahozkoen zein arkitektura-elementuen azterketarekin batera, lurzoruen zundaketetan oinarritutako metodologia geoarkeologiko bat aplikatu da, zenbait adierazle fisiko-kimikoren bidez erresoluzio handiko estratigrafiak zehazteko. Lortutako emaitzek hiru fase bereizteko aukera ematen dute paisaia honen bilakaeran: paisaia 'tradizionalaren' bizkarrezurra osatu zuen (bir)konfigurazio-une bat XIV.-XVI. mendeen artean; intentsifikazio adierazgarri bat XVII.-XIX. mendeen artean, labore amerikarren sarrerak eragindako iraultzari lotuta; eta gainbehera bizkor bat XX. mendeaz geroztik.

\section{RESUMEN}

El caserío, entendido como un paisaje formado por unidades domésticas autónomas distribuidas de manera dispersa, constituye el principal modelo de ocupación del espacio rural en la vertiente atlántica del País Vasco. En las últimas décadas, el estudio arqueológico de muchos caseríos ha permitido definir series tipo-cronológicas de gran detalle para este tipo de edificios. El presente trabajo propone abordar el estudio de los paisajes culturales articulados por el caserío, integrando el estudio de las trazas materiales de los usos agrarios del pasado, como el acondicionamiento de espacios productivos específicos o determinadas prácticas de gestión, con la evolución de las formas arquitectónicas. El análisis se centra en el ejemplo de Zizurkil (Gipuzkoa). Junto con la recopilación de fuentes documentales y orales y el estudio de los elementos arquitectónicos, se ha implementado una metodología geoarqueológica basada en el análisis de diversos parámetros físico-químicos de los suelos de cultivo, con el fin de establecer estratigrafías de alta resolución. Los resultados obtenidos permiten distinguir tres fases en la evolución de este paisaje: un momento de (re)configuración de su estructura básica en los siglos XIV-XIV; una importante intensificación en los siglos XVII-XIX, de la mano de la revolución agraria que siguió a la introducción de cultivos americanos; y una rápida degradación desde mediados del siglo XX.

\section{ABSTRACT}

The Atlantic sector of the Basque Country is characterised by a particular settlement pattern known as baserria, consisting of dispersed, individual farmsteads with autonomous landholdings. Over the last few decades, the architecture of these farmsteads has been studied from an archaeological point of view, resulting in detailed typo-chronological series on the evolution of aspects like constructive materials and techniques or the functional division of the domestic and productive spaces. In this paper, we propose widening this analytical framework by adopting a landscape-based approach that considers not only the architecture of domestic units, but also the material traces of past social practices in the surrounding agricultural areas (e.g., the creation of specific productive spaces or the imprints of specific management practices, like manuring or liming). To this scope, we propose an intensive local study based on the village of Zizurkil (Gipuzkoa, Basque Country). We have applied a transdisciplinary methodology based on the combined analysis of documentary and oral sources, architectural features

\footnotetext{
(1) Aranzadi Zientzia Elkartea.

(2) Euskal Herriko Unibertsitatea. Ondarearen eta Paisaia Kulturalen Ikerketa Taldea.

(3) Euskal Herriko Unibertsitatea. Ikasketa Klasikoen Saila.

(4) Burgoseko Unibertsitatea. Historia, Geografia eta Komunikazio Saila.

*Harremanetarako helbidea: Zorroagagaina, 11 - 20014 Donostia. Email: jnarbarte@aranzadi.eus
} 
present in the local landscape, and geoarchaeological core sampling. Sampled soil records have been analysed using different physical and chemical proxies (XRD, XRF, and LOI, along with radiocarbon dating) to define a high-resolution stratigraphic characterisation. Our results show three main phases in the evolution of the local rural landscape: 1) a moment of (re)configuration that originated the backbone of the 'traditional' landscape between the $14^{\text {th }}$ and $16^{\text {th }}$ centuries; 2 ) a significant intensification linked to the introduction of American crops, such as maize, between the $17^{\text {th }}-19^{\text {th }}$ centuries; and 3) a rapid degradation since the mid-20th century.

\section{SARRERA}

Euskal historiografiak aspalditik aztertu izan du baserriaren fenomenoa, isurialde atlantiarreko landa okupazio-eredu bereizgarri gisa (Ainz, 2001). Ereduaren lehen deskribapenetako bat Manuel Larramendik egin zuen Gipuzkoako Korografian (1882): landetxeak etxalde edo baserri gisa sailkatu zituen, herriekiko zuten kokapen hurbilago edo urrunagoaren arabera; baina, aldi berean, ohartarazi zuen bi terminoak nahasteko joera gero eta handiagoa zela. XIX. mendeko genero-literaturak ${ }^{1}$ eta $X X$. hasierako etnografiak ${ }^{2}$ indartu egin zuten baserri sakabanatuaren ideia, unitate sozial eta produktibo autonomo gisa. Azken hamarkadetan, ikerketa arkeologiko ugari ere egin dira baserriaren dimentsio materialaren, hots, arkitekturaren inguruan. Eraikuntza-materialak eta teknikak, espazioaren banaketa funtzionala edota altxaeren estratigrafia bezalako alderdiak jorratuz, xehetasun handiko serie tipo-kronologikoak eta eskualdeko barietateak definitu ahal izan dira (adib. Ibáñez \& Agirre, 1998; Santana et al., 2001; Duvert, 2012; Telleria et al., 2020), eta egitura asko Euskal Kultur Ondarearen inbentarioetan ere txertatu dira ${ }^{3}$.

Haatik, ez da hein berean garatu baserriek artikulatzen duten paisaia kulturalaren inguruko ezagutza. Historiografiaren zein ondarearen babes-neurrien arreta eraikin indibidualean fokatzean, kasu askotan ez da aztertu eraikinaren presentziak nola eraldatu duen ingurune fisikoa, laborantza- zein abeltzaintza-jarduera desberdinetarako espazioak egokituz eta kasu askotan jatorrizko topografia zein hidrografia eraldatuz. Era berean, baserriek eta inguruko espazio produktiboek osatzen duten harreman-sareak ere ez dira sakonki aztertu; bide-sareen artikulazioa edota habitataren dispertsioa bezalako gaiak, sarri, baserriaren historiari buruzko hausnarketatik at gelditzen dira.

Gabezia hauen aurrean, interesgarria izan liteke baserriak paisaia-testuinguru batean ikertzea, biziguneetatik haratago, espazio produktiboak eta herri-eskalako dinamikak kontutan hartuz. Horretarako, ezinbestekoa gertatzen da informazio-iturri desberdinak baliatzea, tokiko eskalara egokitutako datu-sorta anitz eta adierazkorrak osatzeko. Oinarri metodologiko hauek Britainia Handiko local history korronteak proposatu zituen XX. mende erdialdean (Hoskins, 1954), eta ordutik asko aberastu dira, besteak beste, paisaiaren arkeologiak edota ekologia historikoak egindako ekarpen teoriko eta metodologikoekin (adib., Moreno, 1990; Kirchner, 2010; Aston \& Gerrard, 2013; Stagno, 2018). Halaber, azken hamarkadetan gero eta arreta handiagoa jaso du lurzoruen azterketak, iraganeko prozesuen artxibo gisa ulertuta (Russell, 1997). Euskal Herrian, molde honetako proposamenak ugaritu egin dira azken urteetan, emaitza esanguratsuekin (adib., Narbarte et al., 2019; 2020; 2021). Lan honen xedea, beraz, printzipio hauek baserri-paisaiaren berezitasunei egokitzea da, tokiko ikerketa-kasu baten azterketan oinarrituta.

\section{IKERKETA-ESPARRUA}

Analisia Zizurkilgo baserri-paisaian zentratu da (Gipuzkoa). Herri hau Aiztondo haranean kokatuta dago, Oria ibaiaren ezkerraldean (1 irudia).

\subsection{Testuinguru geologikoa}

EAEko Mapa Geologikoak jasotzen duenez, haranaren substratua Keuper fazieseko material triasikoek osatzen dute: Asteasuerreka inguruan buztin nabarrak eta igeltsuak eta diabasa ofitikoak. Iparralderantz, erliebea malkarragoa bihurtzen doa; material jurasikoak (tupak eta kareharriak) zein kretazikoak (hareharri geruzatuak, kareharri bioklastikoak) tartekatzen dira, halaber garapen karstikoa erakusten dutenak puntu jakin batzuetan. Udalerriaren iparraldeko muturra lutita eta hareharri triasikoz eta kretazeoz osatutako Andatza mendilerroak hartzen du, Eskeltzuko tontorra delarik punturik altuena (508 m). Hegoaldean, berriz, Asteasuerreka Orian isurtzen den inguruan, Kuaternarioan osatutako terraza alubialak dira nagusi ${ }^{4}$. Inguru osoa Europako eskualde biogeografiko atlantiarrean kokatuta dago ${ }^{5}$ eta klima ozeanikoa du, urte osoan banatutako tenperatura epel eta prezipitazio ugarirekin.

\footnotetext{
1 Adib., Elizanburu (1855-1867), Loti (1897; 1932); Agirre (1912); Lhande (1914).

2 Ekarpen interesgarrienetariko batzuk Anuario de Eusko Folklore aldizkariaren lehen 14 ataletan argitaratu ziren $1921-1934$ artean. Barandiaran Fundazioa (2020/05/22): barandiaranfundazioa.eus/index.php/es/argitalpenak-2/eusko-folklorearen-urtekaria/1921tik-1934ra. Zenbait ikerlarik lan horri segida eman zioten ondorengo hamarkadetan ere, adib. Barandiaran (1961; 1962); Caro (1944; 1969a; 1969b); Douglass (1975); Greenwood (1976).

${ }^{3}$ Eusko Jaurlaritza, Kultura eta Hizkuntza Politika Saila - Kultur Ondarea (2021/05/22): euskadi.eus/web01-apintegr/eu/y47alntegraWar/ inicio?locale=eu

${ }^{4}$ Energiaren Euskal Erakundea, Euskal Herriko Mapa Geologikoa 1:25.000 eskalan (2021/05/20): eve.eus/Conoce-la-Energia/La-energia-en-Euskadi/Publicaciones/Geologia/Mapa-Geologico-del-Pais-Vasco-a-escala-1-25-00-(1)?lang=eu-es

${ }^{5}$ Europar Komisioa - Natura2000 (2021/04/03): ec.europa.eu/environment/nature/natura2000/platform//knowledge_base/143_atlantic_region_en.htm
} 


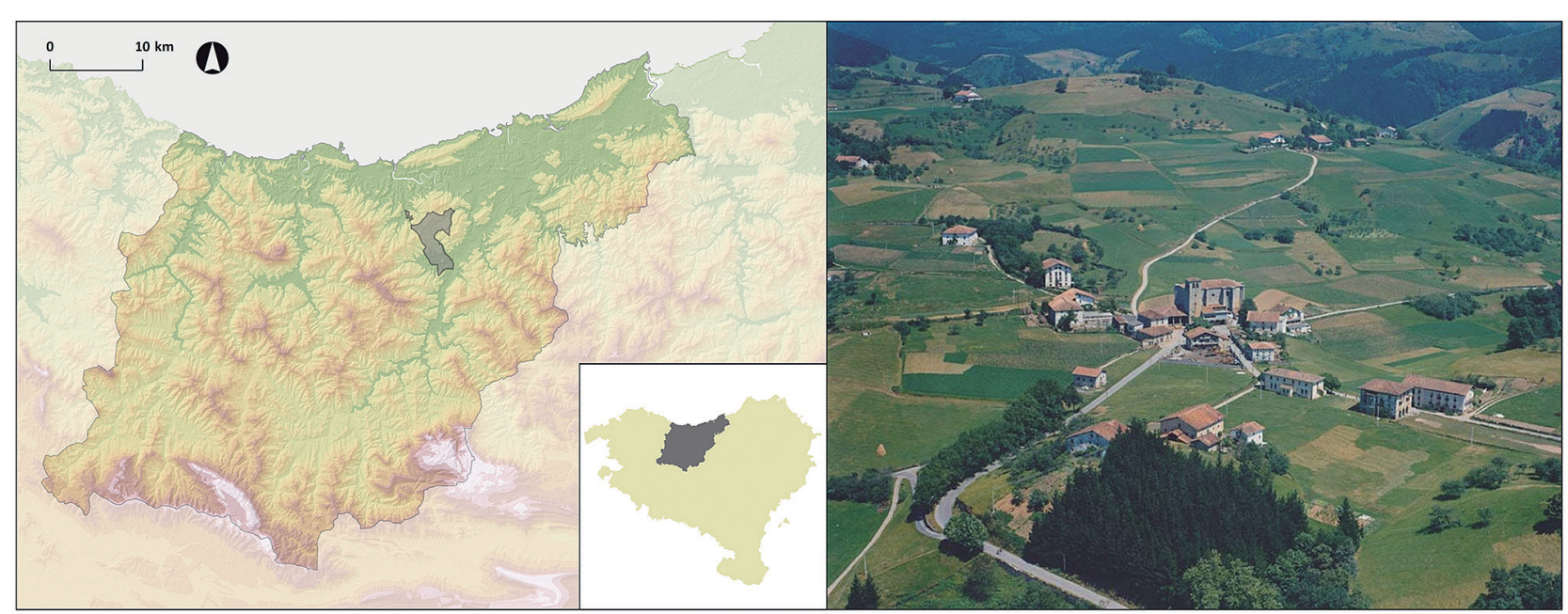

Irudia 1: Zizurkilgo udal barrutiaren kokapena Gipuzkoako eta Euskal Herriko testuinguruan, eta ikuspegi orokorra. Iturria: Gaindegia, Mugibili / Kutxateka. / Location of Zizurkil within the Gipuzkoa province and the Basque Country, and general view. Source: Gaindegia, Mugibili / Kutxateka.

\subsection{Ikerketen egoera}

Herriaren historia hainbat ikerketaren bidez sakondu izan da. Alde batetik, Aranzadi Zientzia Elkarteak argitaratutako Tolosaldea Historia bilduman lau ale eman dira argitara. Lehen hirurek herriaren historia landu zuten, iturri dokumentalen aldetik (Mora, 2005; 2006; Zapirain, 2007); laugarrenak herriko baserrien ikerketa historiko-arkeologikoa gauzatu zuen (Moraza, 2010). Bestalde, Hernandorena kultur taldeak ere nabarmentzeko lana egin du herriko ondare historikoa berreskuratzen eta gizarteratzen ${ }^{6}$. Azkenik, herri-lan desberdinen testuinguruan egindako larrialdiko esku-hartze arkeologikoak aipatu behar dira; hauen memoriak Eusko Jaurlaritzaren Arkeoikuska urtekarian jasota daude ${ }^{7}$. Erreferentzia hauek guztiak abiapuntu gisa baliatu dira hemen aurkeztutako lana abiarazteko.

\section{MATERIALAK ETA METODOAK}

Analisia bi informazio-iturri osagarriren uztartzean oinarritu da batik bat. Alde batetik, baserri-paisaiaren konfigurazio orokorra zehaztu da, iturri dokumentalak eta paisaian presente dauden elementu materialak kontutan hartuta. Bestetik, lurzoruen zundaketak gauzatu dira, iraganeko laborantza-praktiken aztarna materialak dokumentatzeko xedez.

\subsection{Iturri dokumentalak eta arkitektura-elementuak}

Erabilitako iturri dokumentalak udal zein lurralde mailakoak izan dira. Lehen multzoan, Zizurkilgo, Donostiako (Donemiliaga Funtsa) eta Tolosako Udal Artxi- boak arakatu dira; azken horretako iturri garrantzitsuenak argitaratuta daude, Eusko Ikaskuntzaren Fuentes Documentales Medievales del País Vasco bildumaren baitako bi liburukitan (Roldán, 1991; Lema \& Tapia, 1995). Bigarren multzoan, berriz, Gipuzkoako Artxibo Orokorra eta Gipuzkoako Protokoloen Artxibo Historikoa ustiatu dira batik bat, Iruñeko Katedralaren Artxiboarekin osatuta.

Zizurkilgo baserriei lotutako arkitektura-elementu esanguratsuak identifikatzeko, Moraza (2010) da erreferentziazko lana. Horrez gain, Eusko Jaurlaritzaren Ondare Kulturaleko Zentroaren inbentarioak arakatu dira. Haatik, eraikinen arkitekturaren esparru zorrotzetik at gelditzen diren elementuak (lursailen arteko muga-markagailuak, laborantzarako terrazak, ureztatze- eta drainatze-sistemak, etab.) ikertu gabe daude guztiz. Elementu hauen kartografia bat egiteko, begizko miaketa estentsibo bat gauzatu da, XX. mende erditik aurrerako aireko argazkietan oinarritutako fotointerpretazio-lan batekin osatuta. Hala, Zizurkilgo baserrien errealitate materiala bere paisaia-testuinguruan behatu ahal izan da, herri mailako ikuspegi bat lortzeko.

Azkenik, ahozko iturriak ere jorratu dira, herriko hainbat bizilagunekin egindako elkarrizketa erdi-egituratuen bidez. Honako gaiak landu dira elkarrizketa horien bidez: 1) baserrien inguruko landa-espazio desberdinen sailkapena, erabilera eta balio produktiboa zein sinbolikoa; 2) laborantza-praktika tradizionalak eta haien transmisio-moduak; 3) mikro-toponimia; eta 4) azken hamarkadetan izandako aldaketa nagusiak, bai nekazaritza-jardueraren arloan eta baita paisaiaren itxuran ere.

\footnotetext{
${ }^{6}$ Hernandorena Kultur Elkartea (2021/05/10): https://hernandorena.eus/zizurkil.

7 Eusko Jaurlaritza, Kultura eta Hizkuntza Politika Saila - Kultur Ondarea, Arkeoikuska (2021/05/15): euskadi.eus/web01-aparkeo/eu/y47alntegraWar/ PUConsultaController/inicio?locale=eu
} 


\subsection{Lurzoruen zundaketak}

Zizurkilgo paisaiari lotutako lurzoru-erregistroak zundaketa mekanikoak eginez bildu dira. VanWalt/Eijkelkamp perkusio-zunda bat baliatu da horretarako (2 irudia); metodo honek paisaiako puntu estrategikoetan esku hartzeko aukera ematen du, 1 m-ko maniobrak lotuz substratura iritsi arte. Behin jasota, laginak $3-4^{\circ} \mathrm{C}-\mathrm{ko}$ tenperaturan gorde dira, laborategian prozesatu arte.

\subsubsection{Geokimika: X izpien fluoreszentzia (XRF)}

Jasotako erregistro sedimentarioen osaera elementala Bartzelonako Unibertsitateko Corelab laborategian analizatu da, X-izpien fluoreszentzia (XRF) bidez. Analisia $1 \mathrm{~cm}-\mathrm{ko}$ erresoluzioan gauzatu da, Avaatech eskaner bat erabiliz. Alde batetik, $800 \mu \mathrm{A}$-ko X-izpien korrontea, 10 segundoko zenbaketa-tartea eta 110 kVko X-izpien boltajea erabiliz, honako elementuak neurtu dira: Al, Si, P, S, Cl, Ar, K, Ca, Ti, V, Rh, Cr, Mn eta Fe. Beste aldetik, 2000 HA-ko X-izpien korrontea, 25 segundoko zenbaketa-tartea eta 30 kV-ko X-izpien boltajea erabiliz eta $\mathrm{Pd}$ filtro bat gehituta, honako elementuak neurtu dira: $\mathrm{Ni}, \mathrm{Cu}, \mathrm{Zn}, \mathrm{Ga}, \mathrm{Ge}, \mathrm{As}, \mathrm{Br}, \mathrm{Rb}, \mathrm{Sr}, \mathrm{Y}, \mathrm{Zr}, \mathrm{Nb}$ eta $\mathrm{Pb}$. Metodo honek Al eta $U$ bitarteko osaera kimiko elementalaren analisi semi-kuantitatiboa egiteko aukera eman du, elementu bakoitza gainerakoekin alderatuz, segundoko neurketa kopuruan (cps) oinarrituta.

\subsubsection{Osagai Nagusien Analisia (ONA)}

Analisi geokimikoen emaitzak metodo estatistikoen bidez prozesatu dira. Lehenik, lortutako datuak filtratu dira, cps baxuak dituzten elementuak baztertuz eta zalantzazko neurketak (legarrak edota sedimentu disgregatuak dituzten tarteetan, kasu) ezabatuz. Gainerako balioak estandarizatu, eta Osagai Nagusien Analisia gauzatu da (ONA, cf. Giralt et al., 2008; 2011; Margalef et al., 2014), SPSS 23.0 softwarea erabiliz. Lan honen helburua aldagai kopurua Osagai Nagusi (ON) multzo batera murriztea izan da, antzeko bilakaera duten aldagaiak taldekatuz (Hotelling, 1933). Errotatutako (Varimax) eta errotatu gabeko soluzioak aztertu ondoren, kasu bakoitzean datu geokimikoen bariantzari hobekien egokitutakoa hautatu da. Faktore bakoitzaren korrelazio koefizienteak azaldutako bariantza-kopuruaren arabera sailkatu dira: >0.7 korrelazio altutzat jotzen da, elementu jakin baten bariantzaren \%>49 azaltzen baitu; 0.7-0.5 korrelazio moderatutzat jotzen da, bariantzaren \%49-25 azaltzen baitu; eta $<0.5$ korrelazio baxua da, bariantzaren $\%<25$ azaltzen baitu.

\subsubsection{Kimio-estratigrafia}

Abiapuntuko aldagaiak zein lortutako Osagai Nagusiak uztartuta, eta sedimentuen kolorea, testura eta osaera bezalako beste adierazle batzuk ere kontutan atxikita, lurzoru-erregistro bakoitzaren estratigrafia zehaztu da azkenik. Zehaztutako horizonteak USDA-k (2014) proposatutako taxonomiaren arabera sailkatu dira.

\subsubsection{Datazioa}

Behin erregistro bakoitzaren estratigrafia zehaztuta, unitate estratigrafikorik esanguratsuenak erradiokar-

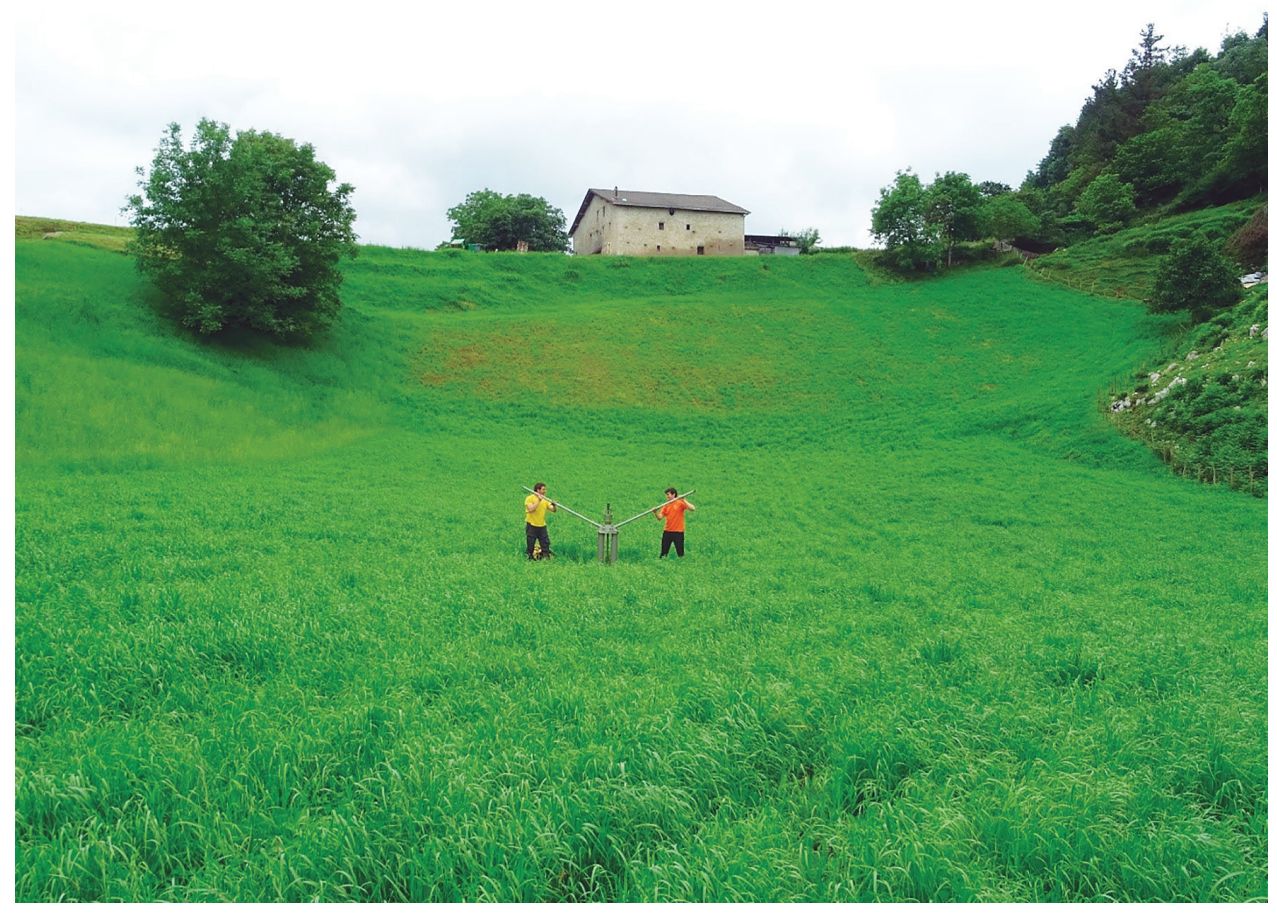

Irudia 2: Zundaketa-lanak Zizurkilgo Azkarate baserriaren azpiko soroan. / Core sampling by the farmhouse Azkarate of Zizurkil. 
bono bidez datatu dira. Laginak Campaniako Unibertsitateko CIRCE laborategian tratatu ondoren, Florentziako Centro Nazionale di Fisica Nucleare zentroan AMS bidez neurtu dira.

\section{EMAITZAK}

\subsection{Iturri dokumentalak eta arkitektura-elementuak}

XIV. eta XX. mendeen artean, orotara 119 baserri desberdin dokumentatzen dira Zizurkilen. Horien artean, multzo handi bat Behe Erdi Aroako agirietan aipatuta ageri da, eta gainerakoak Aro Modernoan zehar (I taula \& 3a irudia). Haien kokapena GeoEuskadi biso- rean $^{8}$ zein Zizurkilgo Udal Mapa Toponimikoan ${ }^{9}$ kontsulta daiteke.

Etxe horietatik, 91 zutik daude oraindik eta 55ek arkitektura-elementu historikoak dituzte (I taula \& 3b irudia). Zaharrenak baserri gotiko-errenazentistaren tipologia desberdinei dagozkie; Morazak (2010) XVI. mendeko kronologiak estimatzen ditu gehienentzat. Baserri hauen artean, 9 Euskal Kultur Ondarearen datu-baseetan inbentariatuta daude Balizko Arkeologia Eremu gisa; bik XIV. mendeko elementuak lituzkete, lauk XV.ekoak eta hiruk XVI.ekoak. Hala ere, kontserbatutako egitura gehienak berantiarragoak dira, harian-harian egindako berreraikuntzen ondorio. a)

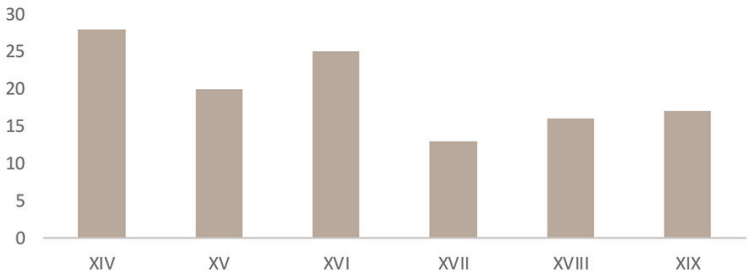

b)

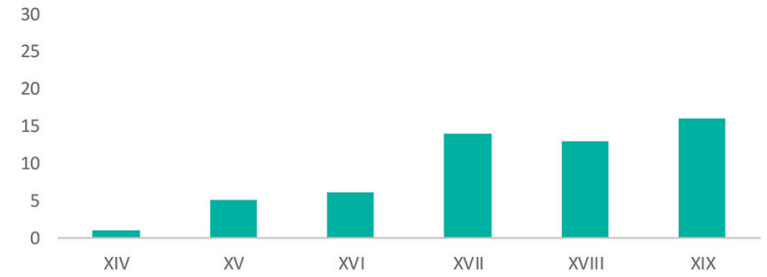

Irudia 3: Zizurkilgo baserrien kronologia. (a) Iturri dokumentalen arabera. (b) Kontserbatutako arkitektura-elementuen arabera. Iturria: Testuan aipatutakoak eta Moraza (2010) / Chronology of farmsteads in Zizurkil. (a) After documentary sources. (b) After conserved architectural elements. Source: records mentioned in the text and Moraza (2010).

\begin{tabular}{|c|c|c|c|c|c|}
\hline \multirow{2}{*}{ Izena } & \multicolumn{2}{|c|}{ Lehen aipamen dokumentalak } & \multicolumn{2}{|c|}{ Arkitektura-elementuak } & \multirow{2}{*}{ Oharrak } \\
\hline & Antroponimo gisa & Etxe gisa & Eusko Jaurlaritza & Moraza (2010) & \\
\hline Abeletxe & & 1761 & & Eraberritua & Borda izandakoa \\
\hline Adunibar & & 1570 & & Barrokoa (XVII) & Errota \\
\hline Agirre & 1391 & 1590 & & Neoklasikoa (XIX) & \\
\hline Akezkoerrota & & 1703 & & Barrokoa (XVIII) & Errota \\
\hline Alkaniz & & 1703 & & Eraberritua & Errota \\
\hline Alkitrai & & 1816 & & Egitura soila (XIX) & Herri-lur izandakoetan \\
\hline Altxurriaga & & 1618 & & Neoklasikoa (XIX) & Sarobe izandakoa \\
\hline Altziturri & & 1618 & & Desagertua & Errota \\
\hline Amabi & & 1668 & & Barrokoa (XVIII) & \\
\hline Andia & 1391 & 1562 & $X I V-X V$ & Gotiko-errenazimentala (XVI) & \\
\hline Andiberri & & 1665 & & Desagertua & Borda izandakoa \\
\hline Andizabal & 1391 & 1573 & & Eraberritua & \\
\hline Andrezketa & 1475 & 1595 & $X V$ & Gotiko-errenazimentala (XVI) & \\
\hline Apaizetxea & & 1618 & & Errenazimentala (XVII) & \\
\hline Arandabarro & 1475 & 1696 & & Eraberritua & \\
\hline Arangaitz & & 1618 & & Eraberritua & \\
\hline Areta azpikoa & 1391 & 1547 & & Barrokoa (XVII) & \\
\hline Areta goikoa & 1391 & 1692 & & Barrokoa (XVII) & \\
\hline Argurutzea & & 1577 & & Desagertua & \\
\hline Arizkurutzeta & & 1539 & & Neoklasikoa (XIX) & Sarobe izandakoa \\
\hline
\end{tabular}

\footnotetext{
${ }^{8}$ GeoEuskadi bisorea (2021/09/18): https://www.geo.euskadi.eus/s69-bisorea/eu/x72aGeoeuskadiWAR/index.jsp?lang=eu

${ }^{9}$ EAEko Udal Mapa Toponimikoak - GeoEuskadi (2021/09/18): https://www.euskadi.eus/eaeko-udal-mapa-toponimikoak/web01-ejeduki/es/
} 


\begin{tabular}{|c|c|c|c|c|c|}
\hline \multirow{2}{*}{ Izena } & \multicolumn{2}{|c|}{ Lehen aipamen dokumentalak } & \multicolumn{2}{|c|}{ Arkitektura-elementuak } & \multirow{2}{*}{ Oharrak } \\
\hline & Antroponimo gisa & Etxe gisa & Eusko Jaurlaritza & Moraza (2010) & \\
\hline Arizmendi & 1391 & 1590 & & Eraberritua & \\
\hline Arizmendizabal & & 1843 & & Neoklasikoa (XIX) & \\
\hline Arrieta & 1470 & 1691 & & Eraberritua & \\
\hline Arritxipi & & 1596 & & Eraberritua & \\
\hline Artutxaenea & & 1829 & & Kale-etxea (XIX) & \\
\hline Astabere & & 1632 & & Neoklasikoa (XIX) & \\
\hline Atxulondo & & 1470 & $\mathrm{XV}$ & Burdinola $(X V)$ & Burdinola/errota \\
\hline Azkarate & 1391 & 1592 & & Barrokoa (XVIII) & \\
\hline Beibategi & & 1692 & & Eraberritua & \\
\hline Beldarrain & & 1765 & & Desagertua & \\
\hline Benezia & & 1595 & & Desagertua & \\
\hline Bengoetxea & 1457 & 1570 & & Eraberritua & \\
\hline Berastegi & & 1549 & $\mathrm{XV}$ & Gotiko-errenazimentala (XVI) & \\
\hline Bidegurutze & 1540 & 1618 & & Neoklasikoa (XIX) & \\
\hline Bidegurutzeberri & & 1847 & & Desagertua & \\
\hline Bikarioetxezar & & 1855 & & Barrokoa (XVIII) & \\
\hline Burrustidi & & 1732 & & Eraberritua & \\
\hline Donemiliaga & & 1470 & XIV & Gotiko-errenazimentala $(\mathrm{XV})$ & \\
\hline Egieta & & 1699 & & Eraberritua & \\
\hline Elizalde & 1470 & 1577 & & Barrokoa (XVIII) & \\
\hline Elizondo & & 1878 & & Eraberritua & \\
\hline Errekalde & & 1757 & & Neoklasikoa (XIX) & \\
\hline Erretenbarrendi & 1391 & 1608 & & Gotiko-errenazimentala (XVI) & \\
\hline Etxabe & & 1618 & & Desagertua & \\
\hline Etxabesaletxe & & 1618 & & Neoklasikoa (XIX) & Borda izandakoa \\
\hline Etxeberria & 1391 & P. 1500 & & Desagertua & \\
\hline Etxeberritxiki & $1532 ?$ & 1618 & & Eraberritua & \\
\hline Etxeberritxo & & 1759 & & Gotiko-errenazimentala (XVI) & \\
\hline Etxetxo & & $1750 \mathrm{O}$. & & Eraberritua & Borda izandakoa \\
\hline Etzeta & & 1746 & & Eraberritua & \\
\hline Fraisoro & 1475 & 1568 & & Desagertua & \\
\hline Galardi & 1391 & 1584 & & Neoklasikoa (XIX) & \\
\hline Garadi & 1541 & 1618 & & Desagertua & \\
\hline Garetza & 1391 & 1575 & & Eraberritua & \\
\hline Garmendi & & 1692 & & Eraberritua & \\
\hline Goikoetxea & & 1835 & & Desagertua & Herri-lur izandakoetan \\
\hline Gurutzeta & & 1828 & & Eraberritua & Herri-lur izandakoetan \\
\hline Ihartza & 1391 & 1618 & & Barrokoa (XVII) & \\
\hline Illarratxoeta & & 1814 & & Desagertua & Herri-lur izandakoetan \\
\hline Ipidegi & & 1865 & & Desagertua & Herri-lur izandakoetan \\
\hline Iragorri & 1391 & 1590 & & Gotiko-errenazimentala (XVI) & \\
\hline Iraola & 1391 & 1598 & & Neoklasikoa (XIX) & \\
\hline Irazibar & 1391 & 1553 & & Gotiko-errenazimentala (XVI) & \\
\hline Irazuazpikoa & 1391 & 1548 & $X V$ & Eraberritua & \\
\hline Irazugoikoa & 1475 & 1618 & $\mathrm{XVI}$ & Gotiko-errenazimentala (XVI) & \\
\hline Iriarte & 1470 & 1689 & & Eraberritua & \\
\hline Iruin & 1391 & 1598 & & Eraberritua & \\
\hline
\end{tabular}




\begin{tabular}{|c|c|c|c|c|c|}
\hline \multirow{2}{*}{ Izena } & \multicolumn{2}{|c|}{ Lehen aipamen dokumentalak } & \multicolumn{2}{|c|}{ Arkitektura-elementuak } & \multirow{2}{*}{ Oharrak } \\
\hline & Antroponimo gisa & Etxe gisa & Eusko Jaurlaritza & Moraza (2010) & \\
\hline Iturralde & 1475 & 1596 & & Eraberritua & \\
\hline Itzumitz & & 1536 & & Desagertua & Sarobe izandakoa \\
\hline Kamioaundi & 1470 & 1743 & & Neoklasikoa (XVIII) & \\
\hline Kamiotxiki & & 1776 & & Eraberritua & \\
\hline Landare & & 1618 & & Neoklasikoa (XVIII) & \\
\hline Larretin & 1475 & 1602 & & Neoklasikoa (XIX) & \\
\hline Larrondobuno & 1391 & 1553 & & Barrokoa (XVII) & \\
\hline Legargain & & 1726 & & Barrokoa (XIX) & Borda izandakoa \\
\hline Legarralde & 1391 & 1576 & $\mathrm{XVI}$ & Gotiko-errenazimentala (XVI) & \\
\hline Lizamuño & 1470 & 1623 & & Desagertua & \\
\hline Lizardi & & 1862 & & Desagertua & Borda izandakoa \\
\hline Loidi & & 1618 & $\mathrm{XVI}$ & Barrokoa (XVII) & \\
\hline Loidierrota & & 1862 & & Errota (XIX) & Errota \\
\hline Luzuriaga & 1391 & 1578 & & Neoklasikoa (XVIII) & \\
\hline Makura & 1470 & 1722 & & Eraberritua & \\
\hline Malkorra & & 1745 & & Desagertua & Borda izandakoa \\
\hline Mendigain & & 1618 & & Desagertua & \\
\hline Miranda & & 1618 & & Eraberritua & \\
\hline Mugiroberri & & 1708 & & Desagertua & Borda izandakoa \\
\hline Mugirozar & & 1618 & & Eraberritua & \\
\hline Mutio & 1475 & 1575 & & Eraberritua & \\
\hline Nekola & 1391 & 1553 & & Barrokoa (XVII) & \\
\hline Odolkierraga & & 1648 & & Barrokoa (XVII) & \\
\hline Oiartzun & & 1853 & & Desagertua & Herri-lur izandakoetan \\
\hline Olatza & 1549 & 1618 & & Barrokoa (XVII) & \\
\hline Olentzaroetxeberri & & 1830 & & Neoklasikoa (XIX) & \\
\hline Olentzarozahar & & 1544 & & Barrokoa (XVIII) & \\
\hline Otazu & 1391 & 1618 & & Eraberritua & \\
\hline Pagamendi & 1470 & 1539 & & Eraberritua & Sarobe izandakoa \\
\hline Pagamuño & 1391 & 1539 & & Desagertua & \\
\hline Plazaetxeberri & & 1786 & & Barrokoa (XVII) & \\
\hline Portxeta & 1470 & 1608 & & Barrokoa (XVII) & \\
\hline Sagasti & 1457 & 1618 & & Desagertua & \\
\hline Saizar & 1391 & 1618 & & Eraberritua & \\
\hline Salugarate & 1391 & 1696 & & Barrokoa (XVII) & \\
\hline San Migel & & 1791 & & Eraberritua & \\
\hline Saratxoeta & & 1542 & & Desagertua & Sarobe izandakoa \\
\hline Sarobe & & 1717 & & Barrokoa (XVIII) & Sarobe izandakoa \\
\hline Susperro & 1457 & 1618 & & Desagertua & \\
\hline Torre & & 1608 & & Desagertua & \\
\hline Ugare & & 1611 & & Desagertua & \\
\hline Ugarte & 1391 & 1616 & & Eraberritua & \\
\hline Ugartetxeberri & & 1825 & & Desagertua & \\
\hline Zalduazpikoa & 1391 & 1590 & & Gotiko-errenazimentala (XVII) & \\
\hline Zaldugoena & 1391 & 1600 & & Eraberritua & \\
\hline Zalduzar & & 1618 & & Barrokoa (XVIII) & \\
\hline Zarapegi & & 1822 & & Eraberritua & Herri-lur izandakoetan \\
\hline
\end{tabular}




\begin{tabular}{|c|c|c|c|c|c|}
\hline \multirow{2}{*}{ Izena } & \multicolumn{2}{|c|}{ Lehen aipamen dokumentalak } & \multicolumn{2}{c|}{ Arkitektura-elementuak } & \multirow{2}{*}{ Oharrak } \\
\cline { 2 - 5 } & Antroponimo gisa & Etxe gisa & Eusko Jaurlaritza & Moraza (2010) & \\
\hline Zarateko Benta & & 1619 & & Eraberritua & Herri-lur izandakoetan \\
\hline Zaratetxeberri & & 1833 & & Desagertua & Borda izandakoa \\
\hline Zearsoro & & 1696 & & Eraberritua & Neoklasikoa (XIX) \\
\hline Zubiaurre & & 1618 & & Eraberritua & \\
\hline Zubimusu & & 1760 & & & \\
\hline
\end{tabular}

Taula I: Zizurkilgo baserrien zerrenda. Iturria: Testuan aipatutakoak eta Moraza (2010). / List of farmsteads in Zizurkil. Source: records mentioned in the text and Moraza (2010).

\subsection{Lurzoruen zundaketak}

\subsubsection{ZIZ/1 zundaketa}

ZIZ/1 zundaketa 3 m-ko erregistroak osatzen du eta herrigunetik metro gutxira jaso da, Azkarate baserriaren oinetan dagoen dolina batean.

Erregistroaren osaera kimikoaren bariazioak 4 Osagai Nagusietan (ON) laburbiltzen dira (4 irudia). Oro- tara, hauek \%73 azaltzen dute. ON1ek bariantzaren \%40,9 azaltzen du. K, Sr, Si, Ti, Rb, Al, Y eta V elementuek korrelazio positibo altua dute $(>0,7)$; S-k, berriz, korrelazio negatibo moderatua du $(0,7-0,5)$. Oro har, elementu litogeniko hauen bariazioak kuartzoz edota buztin mineralez osatutako sedimentu siliziklastikoen presentziarekin lot litezke (Koinig et al., 2003; Kylander et al., 2011), tokiko lurzoruen frakzio esanguratsuena
K 0 ON1

$\begin{array}{cc}K & 0,91181482 \\ \text { Sr } & 0,91146811 \\ & =0,8892815\end{array}$

$\begin{array}{ll}\text { Sr } & 0,91146811 \\ \text { Si } & 0,88928415\end{array}$

$\begin{array}{lll}\text { Si } & 0,88928415 \\ \text { Ti } & 0,88733912 \\ \text { Si } & 0,80572599\end{array}$

Rb 0,88572599

Al 0,88440831

$\begin{array}{lll}\text { Y } & 0,75413885 \\ \text { V } & 0,74490741 \\ \text { 2 } & 0,590259\end{array}$

$\begin{array}{lll}\text { Zr } & 0,57901299 \\ \text { Nb } & 0,52483657\end{array}$

a)

Fe 0,50061033

Mn 0,2128097

Pb 0,20356093

$\begin{array}{ll}\text { Cl } & 0,18001222 \\ \text { Ca } & 0,1565178\end{array}$

$\begin{array}{ll}\text { Zn } & 0,10263496 \\ \text { Cr } & 0,05783676\end{array}$

Br $-0,0538368$

$\begin{array}{ll}\text { P } & -0,2742626 \\ \text { S } & -0,5243072\end{array}$
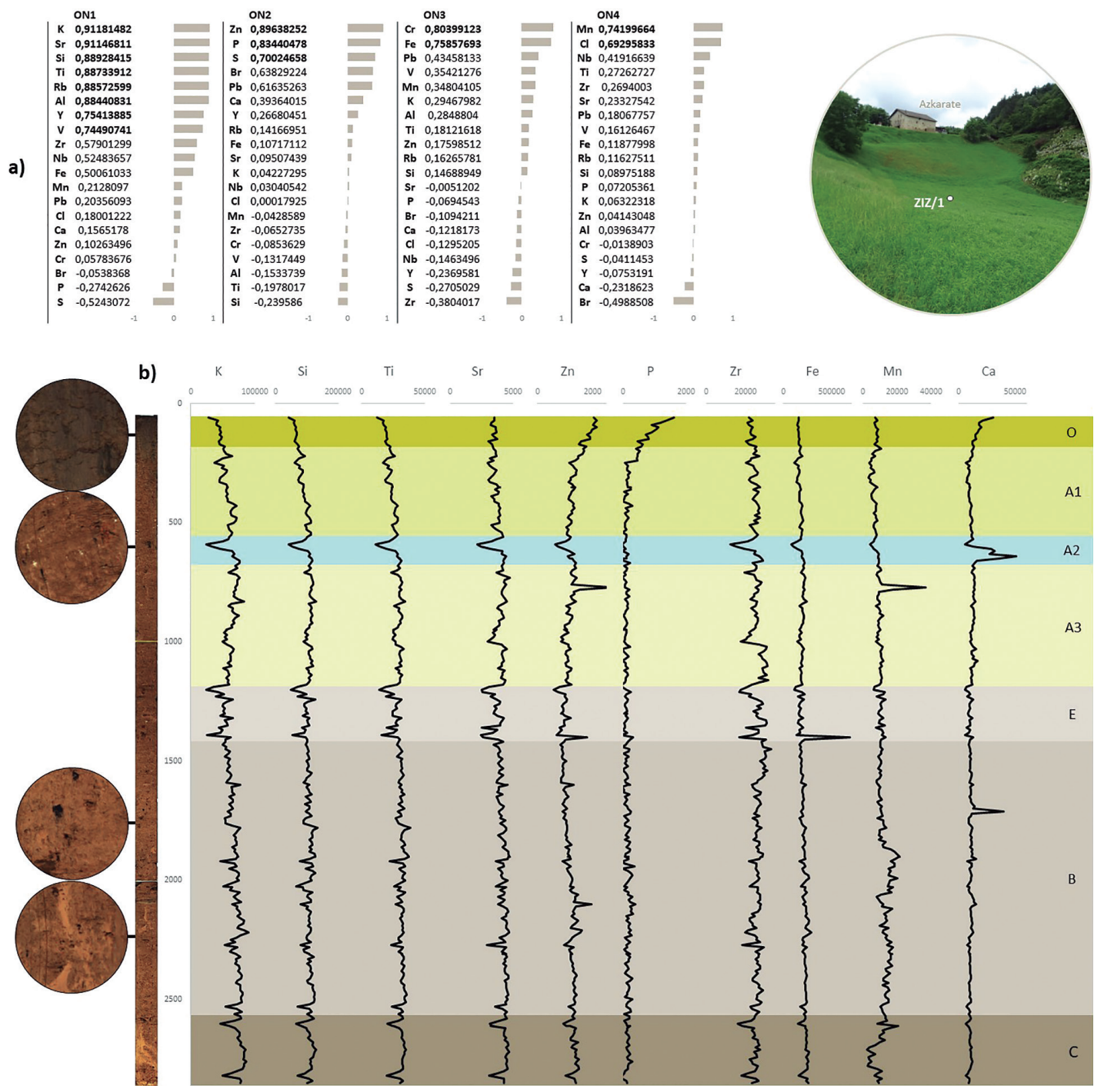

b)
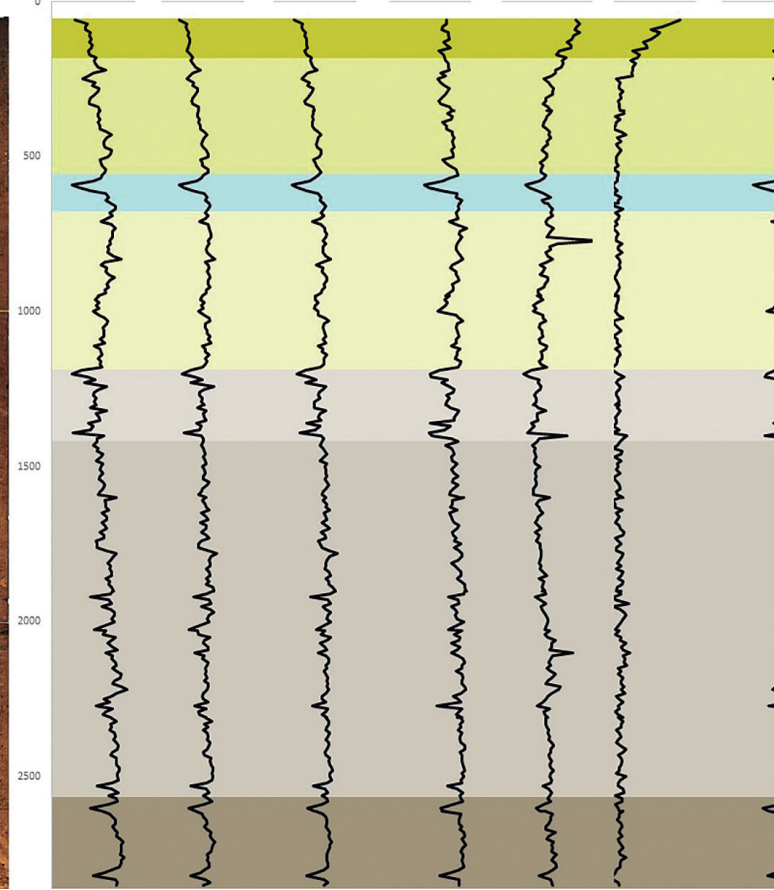

Irudia 4: ZIZ/1 zundaketa. (a) Elementu ezberdinen korrelazio-faktoreak. (b) Elementu ezberdinen banaketa (cps) eta proposatutako estratigrafia I Core ZIZ/1. (a) Factor scores of each element. (b) Element concentrations (cps) and proposed stratigraphy. 
osatzen baitute (adib., Narbarte et al., 2019). ON2k bariantzaren \% 15,76 azaltzen du. Zn, P eta S-k korrelazio positibo altua dute, eta $\mathrm{Br}$ eta $\mathrm{Pb}-\mathrm{k}$ korrelazio positibo moderatua. Elementu hauek materia konposatu organometalikoen zein materia organiko ez-edafikoaren presentzia adieraz lezakete (Huang \& Jin, 2008; Atafar et al., 2010). ON3k bariantzaren \%9,4 azaltzen du. Cr eta Fe-k korrelazio positibo altuak dituzte. ON4k bariantzaren $\% 7$ azaltzen du. Mn-k korrelazio positibo altua du, eta Cl-k korrelazio positibo moderatua. Bi kasu hauetan, lixibiazio eta metal-oxidoen prezipitazioarekin lotuta egon liteke elementu hauen bariantza, erredukzio/oxidazio baldintza aldakorren baitan (Koinig et al., 2003).

Osagai Nagusiak zein abiapuntuko aldagai elementalak kontutan hartuta, zortzi horizonte edafiko bereiz daitezke lurzoru-erregistro honen baitan (4 irudia). Gainazaleko $15 \mathrm{~cm}$-ak materia begetal deskonposatuz osaturiko O horizontea osatzen dute, materia ON2ri lotutako elementuen kontzentrazio handiak eta lurzoruaren kolore ilunak adierazten dutenez. Honen azpitik, A horizonte bat ageri da (20-118 cm), lupetz ilunez osatua; honen ezaugarri nagusia da ON1-en bildutako elementu litogenikoak, balio baxuetatik abiatuta, progresiboki ugaritzen direla eta elementu biofilikoak (ON2), berriz, balio altuetatik abiatuta gutxitzen doazela sakonera handitu ahala. Horizonte hau, era berean, hiru unitatetan bana daiteke: A1 unitateak $(20-55 \mathrm{~cm})$ izaera organikoagoa du; A2 unitatean (55-69 cm), kaltzio (Ca) balio handiak dira ezaugarri bereizgarriena, begi-bistaz ikus daitezkeen kisu ( $\mathrm{CaO}$ ) pinportekin bat eginez; eta $\mathrm{A} 3$ unitatean (69-108 cm) frakzio mineralak hartzen du pisu handiagoa, sedimentuaren kolorea ere argiagoa delarik. Sakonago, E horizonteak (108-143 cm) elementu litogenikoen kontzentrazio txikiagoa erakusten du, meteorizazio kimikoaren ondorioz katioi jakin batzuen lixibiazioak azal lezakeena. Hain zuzen ere, honen azpian dagoen B horizontean (143-256 cm) ugaritu egiten dira elementu horiek eta, batez ere, ON3-n bildutako Zr, Fe eta $\mathrm{Mn}$; buztin arrez osatutako sedimentuan tartekatuta hainbat oxido ikus daitezke, eta horien prezipitazioak azal litzake balio horiek. Azken unitatea $C$ horizonte minerala da (256-300 cm), sustrai-bioturbazio arrastoak erakusten dituen buztin marroi argi eta plastikoz osatua.

\subsection{2. $Z I Z / 2$ zundaketa}

ZIZ/2 zundaketa metro beteko erregistroak osatzen du. Aretagoikoa eta Aretazpikoa baserriek osatutako multzo ondoan jaso da.

Erregistroaren osaera kimikoaren bariazioak 4 Osagai Nagusietan (ON) laburbiltzen dira (5 irudia). Orotara, hauek \%79,8 azaltzen dute. ON1ek bariantzaren \%38,7 azaltzen du. Zn, Zr, Br, Y, P, Sr eta S elementuek korrelazio positibo altua dute; $\mathrm{Nb}$ eta $\mathrm{Pb}-\mathrm{k}$, berriz, korrelazio positibo moderatua; Fe-k korrelazio negatibo altua du. Aurreko kasuan bezala, elementu hauetariko gehienak materia organikoaren presentziarekin lot litezke. ON2k bariantzaren \%26,3 azaltzen du. Ti, Si, Rb, V eta Al-ek korrelazio positibo altua dute, eta $\mathrm{K}$ eta $\mathrm{Nb}-\mathrm{k}$ korrelazio positibo moderatua; elementu litogenikoek kontrolatutako ONa da, beraz. ON3k bariantzaren \%8,6 azaltzen du. Cl-k korrelazio positibo altua du, eta Ca-k korrelazio positibo moderatua. Kasu honetan, sedimentu basaletan karbonatoen presentziarik ez dagoela kontutan harturik, giza jatorriko kisu (CaO) adizioek kontrolatuko lukete ON hau. ON4k bariantzaren \%6,1 azaltzen du. Mn-k korrelazio positibo altua du, eta Pb eta Mo-k korrelazio positibo moderatua.

Osagai Nagusiak zein abiapuntuko aldagai elementalak kontutan hartuta, sei horizonte edafiko bereiz daitezke lurzoru-erregistro honen baitan (5 irudia).
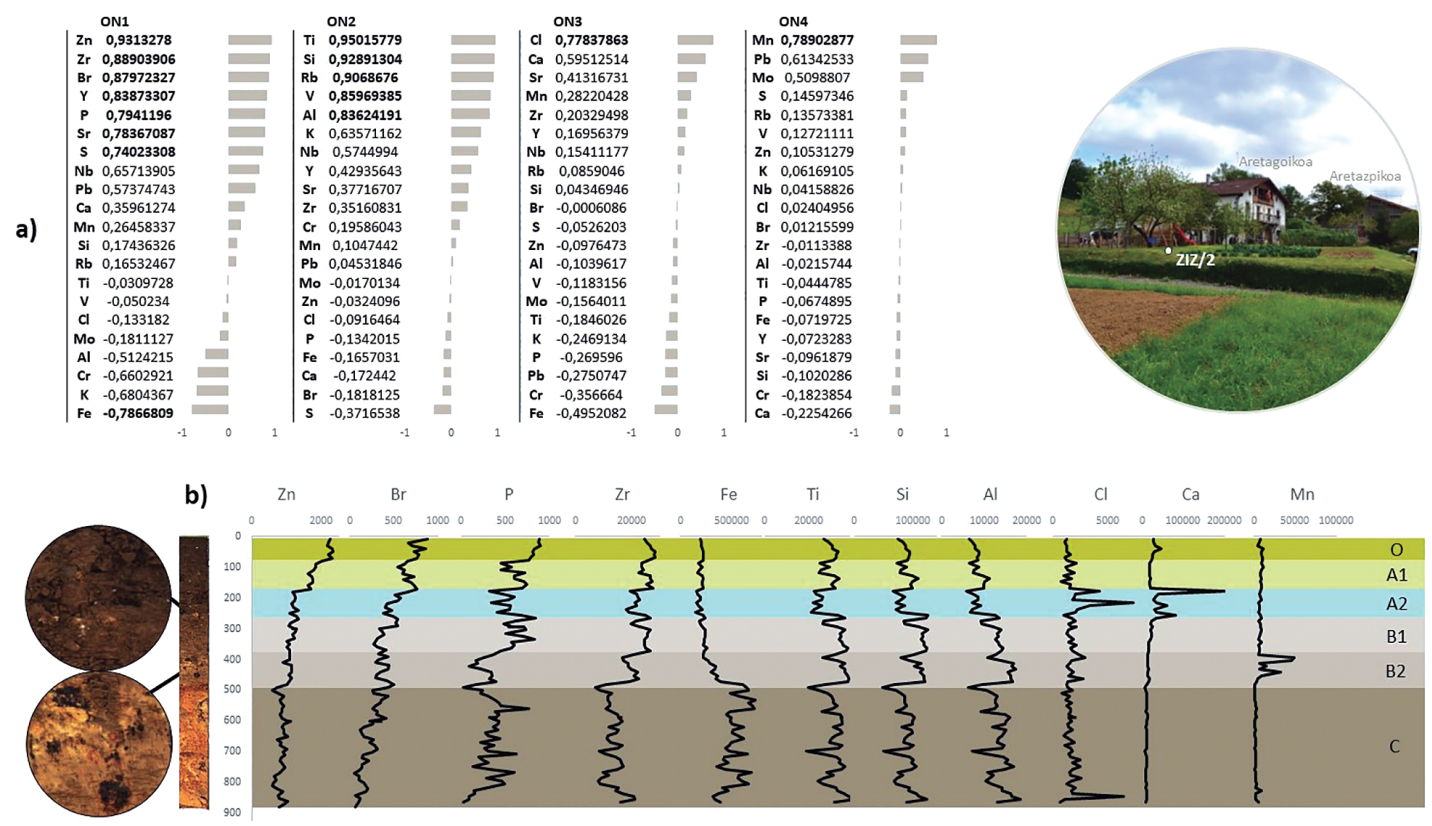

Irudia 5: ZIZ/2 zundaketa. (a) Elementu ezberdinen korrelazio-faktoreak. (b) Elementu ezberdinen banaketa (cps) eta proposatutako estratigrafia I Core ZIZ/2. (a) Factor scores of each element. (b) Element concentrations (cps) and proposed stratigraphy. 
Gainazaleko $8 \mathrm{~cm}$-ak materia begetal deskonposatuz osaturiko $O$ horizontea osatzen dute. Honen azpitik, A horizonteak $(8-27 \mathrm{~cm}$ ) elementu litogenikoen (ON2) hazkunde progresiboa erakusten du, balio baxuetatik abiatuta; elementu biofilikoak (ON1), berriz, balio altuetatik abiatuta gutxitzen doaz sakonera handitu ahala. Horizonte hau, halaber, bi unitatetan banatzen da: A1 unitateak $(8-16 \mathrm{~cm})$ izaera organikoagoa du; A2 unitatean (16-27 cm), berriz, $\mathrm{Cl}$ eta $\mathrm{Ca}(\mathrm{ON} 3)$ balio handiak dira ezaugarri bereizgarriena, begi-bistaz ikus daitezkeen kisu (CaO) pinportekin batera. Sakonago, B horizonte mineral bat ageri da $(27-50 \mathrm{~cm})$, hau ere bi atal desberdinetan banatuta: B1 unitateak $(27-37 \mathrm{~cm})$ osagai organiko handiagoa du, ON1en balioetan islatuta; B2 unitatean (37-50 cm), berriz, osagai hori gutxitu egiten da, eta garrantzia hartzen du Mn (PC4) kontzentrazioak, oxido txikien prezipitazioak azal lezakeena. Azken unitatea C horizonte minerala da (50-88 cm); aipagarria da maila honetan Fe edukia arrunt hazten dela, goragoko balio baxuekin kontrastean.

\subsubsection{ZIZ/4 zundaketa}

ZIZ/4 zundaketa 2 m-ko erregistroak osatzen du eta herrigunetik metro gutxira jaso da, Mutio, Plazaetxeberri eta Kamioaundi baserrien artean dagoen sakonune karstiko txiki baten barruan.
Erregistroaren osaera kimikoaren bariazioak 5 Osagai Nagusietan (ON) laburbiltzen dira (6 irudia). Orotara, hauek \%77,9 azaltzen dute. ON1ek bariantzaren \%43,3 azaltzen du, eta elementu litogenikoen presentziarekin lotuta dago. Zr, Ti, Si, Al eta Nb elementuek korrelazio positibo altua dute, eta $\mathrm{V}, \mathrm{K}, \mathrm{Y}$ eta Rb-k korrelazio positibo moderatua; S-k, berriz, korrelazio negatibo moderatua du. ON2k bariantzaren \%15,9 azaltzen du eta elementu biofilikoak biltzen ditu. Zn eta P-k korrelazio positibo altua dute, eta $\mathrm{Pb}$ eta S-k korrelazio positibo moderatua. ON3k bariantzaren \%8,2 azaltzen du, eta zenbait oxido metalikoren prezipitazioa islatzen du batik bat. Fe, Mn eta Sr-k korrelazio positibo altuak dituzte, eta Br-k korrelazio positibo moderatua; aitzitik, Rb-k korrelazio negatibo moderatua du. ON4k bariantzaren \%5,3 azaltzen du. Cr-k korrelazio positibo moderatua du eta Ca-k, berriz, korrelazio negatibo altua. Azkenik, ON5-ek bariantzaren \%5,2 azaltzen du. Cl-k korrelazio positibo moderatua du, eta Pb-k korrelazio negatibo moderatua.

Osagai Nagusiak zein abiapuntuko aldagai elementalak kontutan hartuta, zazpi horizonte edafiko bereiz daitezke lurzoru-erregistro honen baitan (6 irudia). Gainazaleko 10 cm-ak materia begetal deskonposatuz osaturiko $O$ horizontea osatzen dute. A horizontearen (10-81 cm) ezaugarri nagusia da elementu litogenikoak (ON1), balio baxuetatik abiatuta, progresiboki ugaritzen
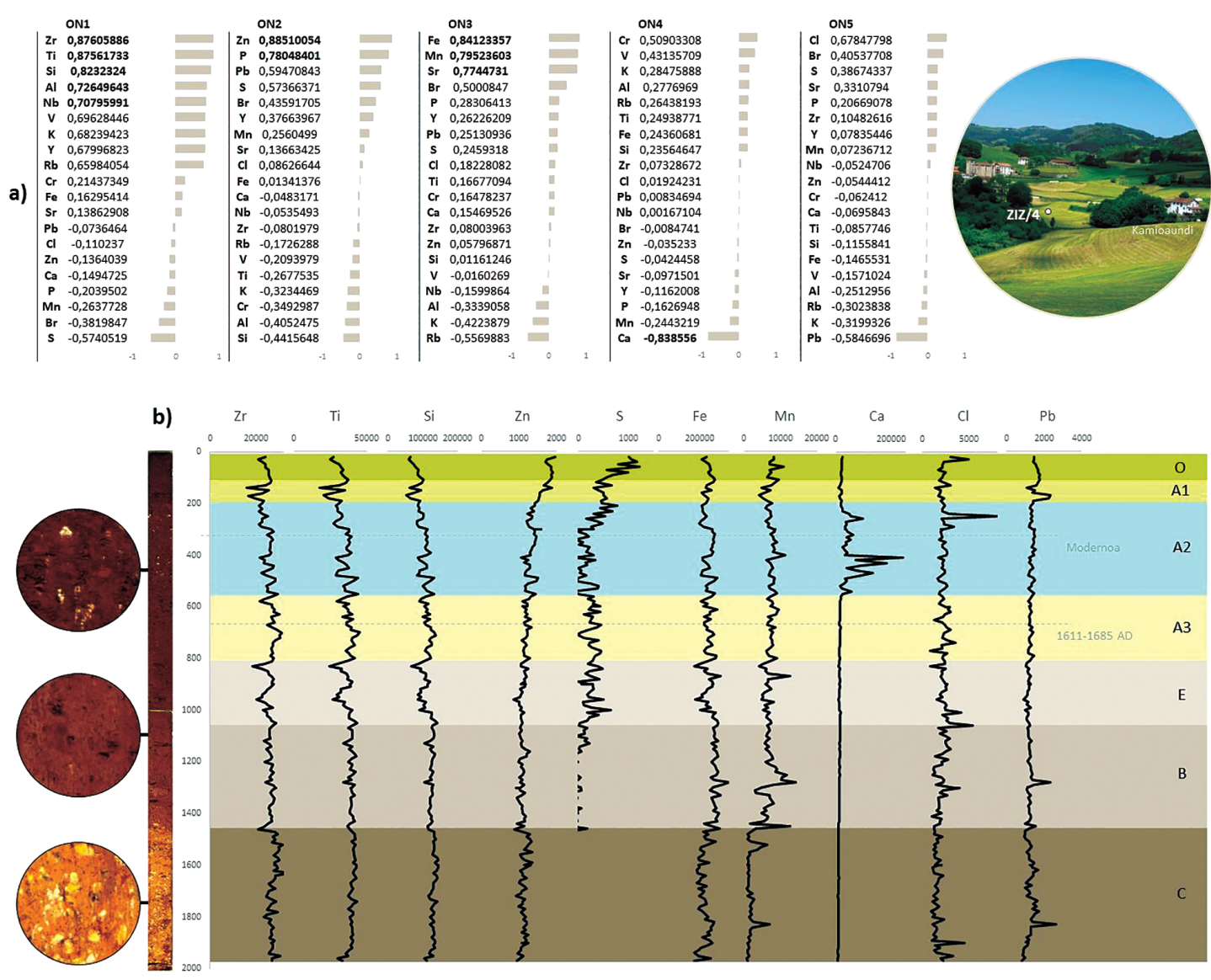

Irudia 6: ZIZ/4 zundaketa. (a) Elementu ezberdinen korrelazio-faktoreak. (b) Elementu ezberdinen banaketa (cps) eta proposatutako estratigrafia I Core ZIZ/4. (a) Factor scores of each element. (b) Element concentrations (cps) and proposed stratigraphy. 
direla eta elementu biofilikoak (ON2 \& ON4), berriz, balio altuetatik abiatuta gutxitzen doazela sakonera handitu ahala. Horizonte hau hiru unitatetan bana daiteke: A1 unitateak $(10-20 \mathrm{~cm})$ izaera organikoagoa du; A2 unitatean (20-56 cm), kaltzio (Ca) balio handiak dira ezaugarri bereizgarriena, begi-bistaz ikus daitezkeen kisu $(\mathrm{CaO})$ pinportekin batera; eta A3 unitatean (56-81 $\mathrm{cm}$ ) frakzio mineralak hartzen du pisu handiagoa. E horizonteak (81-106 cm) elementu litogenikoen kontzentrazio txikiagoa erakusten du, meteorizazio kimikoaren ondorioz katioi jakin batzuen lixibiazioak azal lezakeena. Hain zuzen ere, honen azpian dagoen B horizontean (106-146 cm) ugaritu egiten dira elementu horiek eta, batez ere, ON3-n bildutako Fe eta Mn; sedimentuan tartekatuta hainbat oxido ikus daitezke, eta horien prezipitazioak azal litzake balio horiek. Azken unitatea C horizonte minerala da $(146-200 \mathrm{~cm})$, hainbat klastorekin tartekatutako buztin marroi argi eta plastikoz osatua.

Zundaketa honetan jasotako hiru lagin erradiokarbono bidez datatu dira (II taula). Horietatik, 36 eta 79 cm-ko sakoneran jasotakoek emaitza koherenteak eman dituzte lurzoruaren sekuentzia datatzeko. $76 \mathrm{~cm}$ - an jasotako laginak, aldiz, emaitza inkoherentea eman du, eta baliteke kutsatuta egotea gaineko horizonteetatik infiltratutako kisu-pinporten edota XVIII.-XIX. mendeei eragiten dien Suess efektuaren ondorioz.

\subsubsection{ZIZ/5 zundaketa}

ZIZ/5 zundaketa metro beteko erregistroak osatzen du. Donemiliaga baserri eta dorretxe zaharraren alboko soroan jaso da.

Erregistroaren osaera kimikoaren bariazioak 7 Osagai Nagusietan (ON) laburbiltzen dira (7 irudia). Orotara, hauek \%79,7 azaltzen dute. ON1ek bariantzaren \%33,8 azaltzen du, batik bat elementu litogenikoei lotuta. Al, K, Y, Si, Fe, V eta Rb-k korrelazio positibo altua dute; Ti, Zn eta Cr-k, berriz, korrelazio positibo moderatua; Ca-k korrelazio negatibo moderatua du. ON2k bariantzaren \%13 azaltzen du. Zr eta Nb-k korrelazio positibo altua dute, eta Ti-k korrelazio positibo moderatua; Zn-k korrelazio negatibo moderatua du. ON3k bariantzaren \%9,8 azaltzen du. Sr eta Br-k korrelazio positibo altua dute. ON4k bariantzaren \% 7,3 azaltzen du. S-k korrelazio po-

\begin{tabular}{|c|c|c|c|c|c|c|c|}
\hline Zundaketa & Sakonera & Lagin-mota & Lab. kodea & ${ }^{14}$ C kon. (pMC) & trc (BP urteak) & Kal. data & Kal. data (urteak - 2 s) \\
\hline ZIZ/4 & $36 \mathrm{CM}$ & Ikatza & Fi4230 & $99.51 \pm 0.61$ & Modern & Modernoa & Modernoa \\
\hline ZIZ/4 & $76 \mathrm{CM}$ & Ikatza & Fi4231 & $73.28 \pm 0.51$ & $2498 \pm 56$ & $\begin{array}{r}{[774-727 \mathrm{BC}]} \\
{[718-705 \mathrm{BC}]} \\
{[695-541 \mathrm{BC}]}\end{array}$ & {$[794-430 \mathrm{BC}]$} \\
\hline ZIZ/4 & $79 \mathrm{CM}$ & Ikatza & Fi4233 & $96.93 \pm 0.57$ & $251 \pm 47$ & $\begin{array}{r}{[1523-1572 \mathrm{AD}]} \\
{[1630-1676 \mathrm{AD}]} \\
{[1769-1771 \mathrm{AD}]} \\
{[1941-\ldots \mathrm{AD}]}\end{array}$ & $\begin{array}{r}{[1490-1603 \mathrm{AD}]} \\
{[1611-1685 \mathrm{AD}]} \\
{[1732-1808 \mathrm{AD}]} \\
{[1928-\ldots \mathrm{AD}]}\end{array}$ \\
\hline
\end{tabular}

Taula II: ZIZ/4 zundaketan egindako datazioak / Table II. Dated samples from core ZIZ/4.
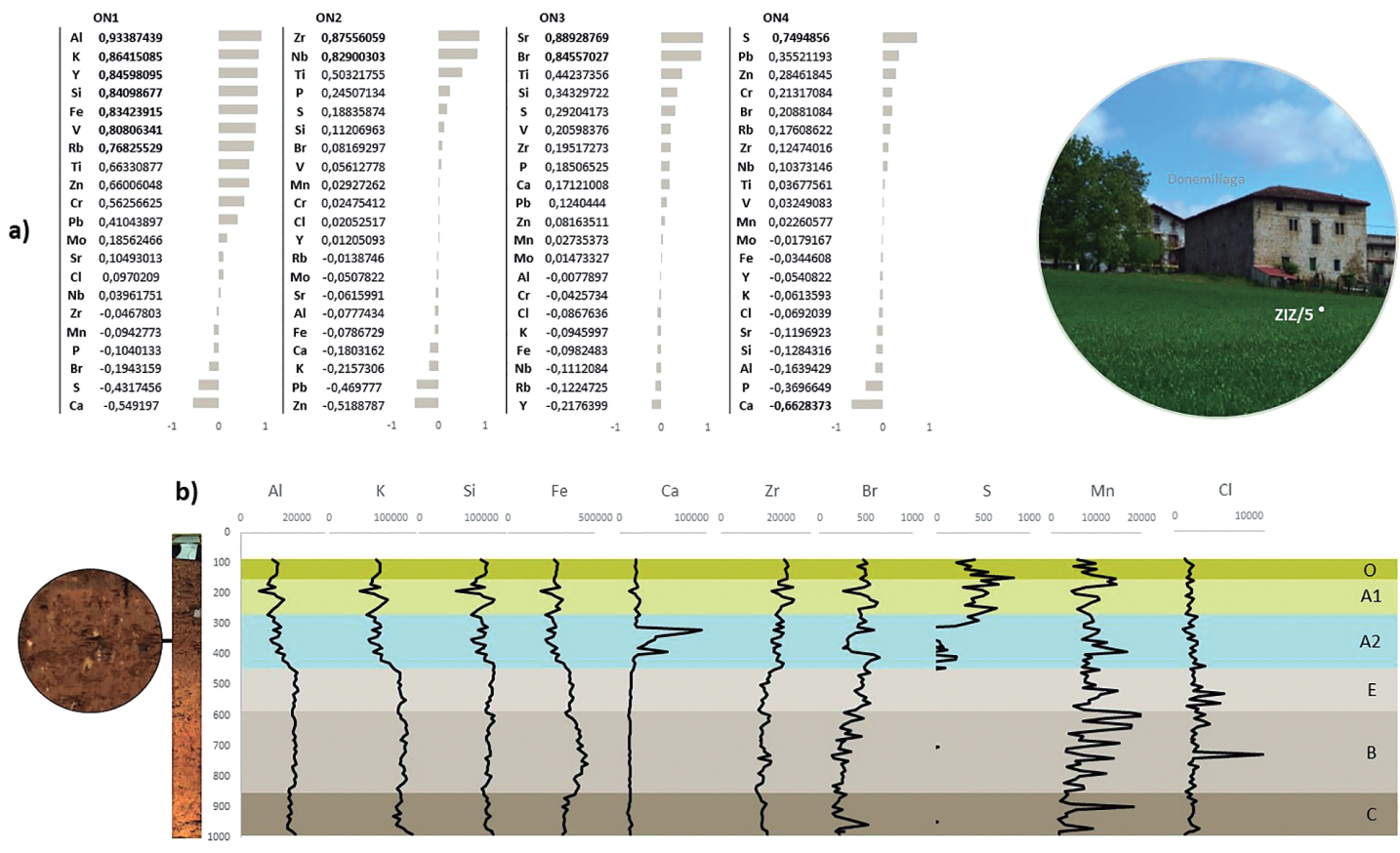

b) $\quad \mathrm{Al}$

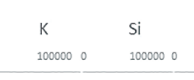
Fe 5000000

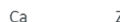

$\mathrm{Zr}$

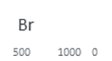

$\mathrm{Mn} \quad \mathrm{Cl}$
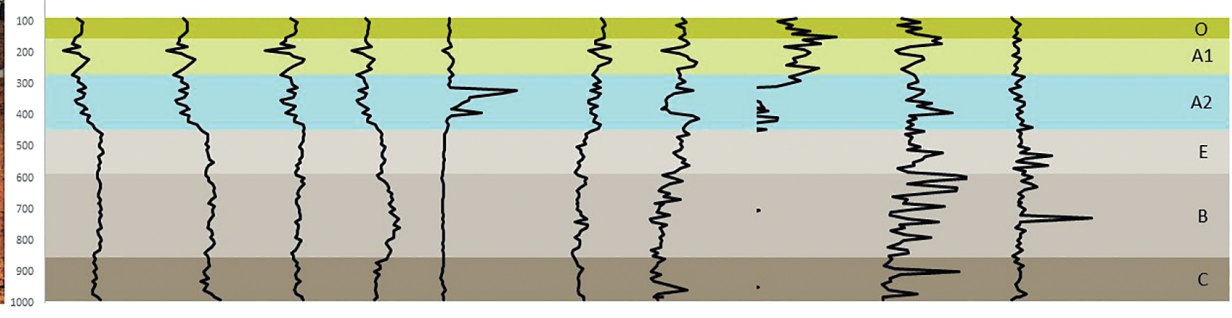

Irudia 7: ZIZ/5 zundaketa. (a) Elementu ezberdinen korrelazio-faktoreak. (b) Elementu ezberdinen banaketa (cps) eta proposatutako estratigrafia / Core ZIZ/5. (a) Factor scores of each element. (b) Element concentrations (cps) and proposed stratigraphy. 
sitibo altua du, eta Ca-k korrelazio negatibo moderatua. Gainerako ONek bariantza-kopuru txikia azaltzen dute, eta elementu bakar baten korrelazio altuak islatzen dituzte: ON5ek $(\% 5,7)$ Mn-rena (eta Pb-ren korrelazio positibo moderatua); ON6k $(\% 5,2) \mathrm{Cl}$-rena; eta ON7k $(\% 4,8)$ Mo-rena.

Osagai Nagusiak zein abiapuntuko aldagai elementalak kontutan hartuta, sei horizonte edafiko bereiz daitezke lurzoru-erregistro honen baitan (7 irudia). Gainazaleko $6 \mathrm{~cm}$-ak materia begetal deskonposatuz osaturiko $\bigcirc$ horizontea osatzen dute. A horizontean (18$43 \mathrm{~cm}$ ), elementu litogenikoak (ON1), balio baxuetatik abiatuta, progresiboki ugaritzen dira; eta elementu biofilikoak (ON3 \& ON4), berriz, balio altuetatik abiatuta gutxitzen doaz. Horizonte hau bi unitatetan banatzen da: A1 unitateak (18-28 cm) izaera organikoagoa du; A2 unitatean (28-43 cm), berriz, Ca (ON4) balio handiak dira ezaugarri bereizgarriena, eta kisu pinportak ere ikus daitezke. Sakonago, E lixibiazio-horizonte bat ageri da (43$56 \mathrm{~cm}$ ), eta honen azpian B prezipitazio-horizonte bat (56-88 cm); bertan Fe eta Mn edukien kontzentrazioak antzematen dira, oxido txikien presentziarekin batera. Azken unitatea $\mathrm{C}$ horizonte minerala da $(88-100 \mathrm{~cm})$.

\section{DISKUSIOA ETA INTERPRETAZIOAK}

Iturri dokumentalak, ahozkoak, arkitektura-elementuak eta lurzoruen zundaketen emaitzak uztartuta, Zizurkilgo paisaiaren historia berreraikitzeko datu baliagarriak jaso ahal izan dira. Funtsean, baserri modernoaren hedapena lotu ahal izan da giza-jarduerak, eta bereziki laborantza-praktika desberdinek, lurzoruetan utzitako aztarnarekin. Hala, bilakaera honetan hiru fase nagusi bereiz daitezke, bakoitza bere ezaugarri propioekin.

\subsection{XIV.-XVI. mendeak: (bir)konfigurazioa}

Zizurkil herriaren sorrera, lurralde jakin batean egonkortutako eta identitate kolektibo baten inguruan bildutako komunitate gisa ulertuta, zaila da denboran finkatzen. Iturri dokumentalei erreparatuta, Zichurchil toponimoa XII. mende bukaeran ageri da aipatuta, Iruñeko elizbarrutiko unitate bat bezala ${ }^{10}$. Hala ere, herriaren beraren inguruko berririk zaharrenak Behe Erdi Aroari dagozkio (Mora, 2005). 1350 inguruan, apezpikutzak egindako agiri fiskal batean, Donemiliagako parrokia agertzen da aipatuta ${ }^{11}$. 1389an, Zizurkildarrek muga-akordio bat sinatu behar izan zuten Orreagako monasterioko ordezkariekin, Andatzako mendi-lurrak banatzeko ${ }^{12}$; itun horrek finkatu zituen herriaren behin betiko mugak. 1391an, berriz, herritarrek auzokidetze-ituna sinatu zuten Tolosako hiribilduarekin ${ }^{13}$. 1435ean, aldiz, honen aurkako salaketa jarri zuten, beste hamahiru herrirekin batera, Valladolideko Erret Kantzelaritzan, banaketa fiskalak zirela-eta. Auzia 1450ean ebatzi zen, herri gehienek Tolosaren eskumen fiskala onartu zutenean; Zizurkil salbuespena izan zen, Donostiarekin bat egin baitzuen ${ }^{14}$. Alabaina, Rodrigo Donemiliagakoa eta bere menpekoak Tolosaren menpera itzuli ziren 1470ean, eta Zizurkilgo kontzejuak gauza bera egin zuen bost urte beranduago ${ }^{15}$. Joan-etorri hauek Erdi Aroaren amaieran Gipuzkoak bizi izan zuen birkonfigurazio sozio-politikoarekin lotuta daude; izan ere, honen lurralde-egitura errege-fundazioko hiribilduek osatutako Hermandade baten esku gelditzean, landa-giroko herriek menpeko rol bat hartu behar izan zuten, hiribildu baten edo bestearen auzo bilakatuta (Truchuelo, 1997).

Agiri hauek islatzen duten herrian hiru elementu nabarmentzen dira. Lehenik, tokiko komunitatea kontzeju baten bidez agertzen da politikoki gorpuztuta, erakunde hori baitzen lurralde jakin baten eta baliabide kolektibo batzuen gaineko eskumena zuena. Bigarrenik, komunitatearen baitako auzotasun-subjektu nagusia etxeak ziren; haiekin identifikatzen ziren norbanakoak, eta haien bidez hartzen zuten parte bizitza kolektiboan. Hirugarrenik, Donemiliagako jaurgoa ere aktore esanguratsu gisa agertzen da. Hura zen herriko parrokia-elizaren - hots, identitate kolektiboaren erreferentzia nagusiaren - titularra (Mora, 2005); gainera, harreman feudala zeukan zenbait auzorekiko, eta horri esker kontzejuaren baitatik at edo haren aurka ere jokatzeko gaitasuna erakusten zuen, 1470an Tolosarekiko adiskidetze-akordioak erakusten duenez.

Donemiliagako dorretxeak eta elizak fisikoki ere posizio zentrala zuten Zizurkilgo paisaiaren baitan. Bi elementu horiek XIV. mendean datatutako arrastoak dituzte, eta herrian kontserbatzen diren aztarna material zaharrenak dira. Haien inguruan egituratzen ziren gainerako etxeak. 1500. urtea baino lehen, aipatutako agiriek 48 etxeren izenak jasotzen dituzte, gehienetan antroponimo gisa; biziguneen erreferentzia zuzenak $\mathrm{XVI}$. mendean hasten dira agertzen, eta 13 etxe berri ere aipatzen dira (I taula). 1618an egindako etxez etxeko ordainketa agiri batean ${ }^{16}$, berriz, lehendik aipatu gabeko 12 etxe berri agertzen dira, eta oso litekeena da horiek ere gutxienez XVI. mendeaz geroztik existitu izana. Haien kokapenari behatuz, argi dago Zizurkilgo

\footnotetext{
${ }^{10}$ Iruñeko Katedraleko Artxiboa, Libro Redondo, 164v; cf. Martínez Díez, 1975 (28 dok.).

${ }^{11}$ Iruñeko Katedraleko Artxiboa, Arca IV Episcopi, 30:6-9.

${ }^{12}$ Zizurkilgo Udal Artxiboa, s/g.

${ }^{13}$ Tolosako Udal Artxiboa, C/5/1/1/4.

${ }^{14}$ Tolosako Udal Artxiboa, C/5/1/1/7.

${ }^{15}$ Tolosako Udal Artxiboa, C/5/1/1/6.

${ }^{16}$ Valladolideko Erret Kantzelaritzako Artxiboa, C3150/1.
} 
habitat-eredua hastapenetik deszentralizatua izan bazen ere, dispertsioa mugatua izan zela fase honetan (3c irudia): dokumentatutako etxe guztiak parrokia-elizatik 2 km-rainoko erradio baten barruan kokatuta zeuden, eta bakarrak (Azkaratek) gainditzen zuen 200 metroko altitudea. Lehen baserri-paisaia, beraz, Andatzaren hegoaldeko magal leunenetan hedatu zen, Asteasu, Adunibar eta Alkaniz errekek mugatuta.

Iturri dokumentalek ez dute argitzen etxe hauek guztiak Erdi Aroaren bukaeran emandako aldaketa baten ondorioz agertu ziren, ala lehenagotik presente ote zeuden tokiko paisaian ${ }^{17}$. Dena den, argi dago garai honetan berrikuntza sakon bat eman zela haien eraikuntza-moldeetan, XV.-XVI. mendeetakoak baitira kontserbatzen diren arkitektura-elementu zaharrenak, 11 baserritan (I taula; 3b irudia). Haien ezaugarriek bat egiten dute beste eskualde batzuetan ohikoak diren baserri gotiko-errenazimentalen tipologiekin, garai honetan Euskal Herri mailan, hiribilduetako merkatuen garapenari erantzuteko eman zen berrikuntzaren lekuko (Gereñu, 2011; Galdos, 2015). Hala, barne-egiturari begira, tolare-baserriak ditugu (Andia, Berastegi, Iragorri, Legarralde) ${ }^{18}$; kanpo-egiturari dagokionez, badira harrizkoak (Andia, Irazugoikoa, Irazibar) zein zurezko bilbaduradunak (Erretenbarrendi, Iragorri) ${ }^{19}$.

$X V I$. mendean izan zen habitat hau jatorrizko herrigunetik at, Andatza mendilerroan gora hedatzeko saiakerarik ere; baina, fase honetan behintzat, porrot egin zuten. 1539an, Zizurkilgo kontzejuak Martin Ruiz Donemiliagakoa salatu zuen, Eskeltzu eta Azarola inguruko herri-lurretan zituen sarobe propioak itxi eta bertan baserriak eraikitzeari ekin baitzion, garia eta artatxikia erein eta haien salmentatik etekinak ateratzeko. Bizilagunek kexu azaldu ziren, abereentzako bazkalekuak gutxitzeak komunitateari kalteak ekarriko zizkiolakoan. Epaia Martin Ruizen kontrakoa izan zen: eraikitako baserri batzuk baimendu arren, gehienak eraistea agindu zion, zeren eta sarobeak "herriaren lurren barruan daude, eta berak [Donemiliagako jaunak] ez du hor beste edozein bizilagunek baino jabetza gehiagorik; eta eskubideren bat baldin badu, abereak bazkatzeko eta babesteko izango da, eta ez bere jabetza osoan erabiltzeko"20.

Orobat, fase honetan baserri modernoa agertu izanarekin lot litezke herriguneko lurzoruetan identifikatu diren antropizazio-zantzuak, laborantzaren garapenari lotuta. Aztertutako zundaketa-erregistroek antzeko profil estra- tigrafikoak erakusten dituzte. Laborantza-zantzuak A horizonte organikoetan kontzentratzen dira, eta hauek hiru unitatetan banatzen dira ZIZ/1 eta ZIZ/4. Bi kasuetan, A3 unitateak dira sakonenak, estratigrafikoki substratu meteorizatutik eratorritako $\mathrm{E}$ eta $\mathrm{B}$ horizonteen gainean kokatuta baitaude. Haien osaera geokimikoak argi erakusten du prozesu pedogenetikoen eragina, jatorrizko sedimentuei lotutako elementu litogenikoen (adib., Al, Si, K, Ti, $\mathrm{Rb}$ ) kontzentrazioak behera egiten baitu azpiko horizonte mineralekin alderatuta, elementu biofilikoak (adib., Zn, P, $\mathrm{Pb}, \mathrm{S}$ ), aldiz, ugaritu egiten diren artean. Bilakaera honek materia organikoaren kontzentrazio gero eta handiagoa islatzen du gainazalerantz; hau landaretzaz estalitako lurzoru baten adierazgarria litzateke, baina giza-jardueren ondorioz ere aberastuta egon liteke — simaur-adizioekin, adibidez.

ZIZ/4 zundaketa Mutio, Plazaetxeberri eta Kamioaundi baserrien artean zabaltzen den dolina zabal batean jaso zen. Haren A3 horizontearen gainazaletik jasotako lagin bat XVII. mendean (1630-1676 cal AD) datatu da erradiokarbono bidez, eta honek ante quem mugarri bat ezartzen du laborantzak moldatutako lurzoru-erregistro hau datatzeko. Baiezta daiteke fase honetako sedimentuak une horretan depositatu zirela; ezin izan da zehaztu noiztik ari ziren lurzoruak garatzen, baina ez dago zalantzarik prozesua martxan zegoela, gutxienez, Erdi Aroaren bukaeraz geroztik. Azkarate baserri azpiko dolinan jasotako ZIZ/1 zundaketaren sekuentzia estratigrafikoa oso antzekoa da, eta antzeko data bat proposa liteke bertako A3 horizontearentzat ere. Bi kasuetan, sakonera handi samarreko A3 horizonte hauen formazioa eta kontserbazioa sakonune karstikoetan emandako agradazio sedimentarioarengatik azal liteke.

Laburbilduz, Erdi Aroaren amaiera eta Aro Modernoaren hasiera bitartean koka daiteke Zizurkilgo baserri-paisaiaren abiapuntua, hiribilduen eta bertako merkatuen garapenari loturik. Garai honetan, tokiko komunitatea lurraldean sakabanatutako etxe-multzo baten gisara konfiguratuta agertzen da, Donemiliaga dorretxeak eta elizak osatutako multzoan duelarik erdigunea. XV.-XVI. mendeetan, etxe hauen arkitektura-moldeek berrikuntza nabarmena ezagutu zuten, lehen baserri modernoak agertu zirelarik; eta horri lotuta dokumenta daitezke laborantzak moldatutako lurzoruak ere. Prozesu honek bat egiten du Euskal Herriko isurialde atlantiarreko beste eskualde batzuetan jaso izan diren

\footnotetext{
${ }^{17}$ Baserriaren inguruko historiografian zabalik dirauen eztabaida da hau. Datu arkeologikoetan oinarrituta, zenbait autorek defendatu dute jarraikortasun bat dagoela Erdi Aroko habitat-ereduaren eta Aro Modernoaren hastapenean agertzen den baserriaren artean; Ezkioko Igartubeiti baserriaren kasuan, adibidez, Goi Erdi Aroko balizko okupazio bat identifikatu zen XVI. mendeko etxearen azpian (Santana et al., 2003), eta Berrizko Besoitaormaetxea, baserrian, aldiz, XII.-XIII. mendeetako okupazio bat (Campos, 2020). Haatik, beste autore batzuek zalantzan jartzen dute jarraikortasun hau; Adunako Aritzaga, Altzoko Zuaznabaraundi, Ezkioko Zelaa edota Lazkaoko Maizgoena baserrietan, kasu, XV. mende bukaeran datatu da baserriaren agerpena, tokiko aurrekaririk batere gabe (Susperregui et al., 2017; Telleria et al., 2020).

${ }^{18}$ Eredu honen hainbat adibide ikertu izan dira Gipuzkoa, besteak beste Gazteluko Etxeberri eta Elduako Etxenagusia (Ibañez \& Agirre, 1998) eta Ezkioko Igartubeiti (Santana et al., 2003).

${ }^{19}$ Tipologia hauen ikuspegi orokor baterako, ikus Santana et al. (2001).

${ }^{20}$ Donostiako Udal Artxiboa, San Millan Funtsa, 109.225.
} 
ebidentziekin, bai baserri modernoaren arkitekturaren aldetik (Santana, 2001), bai eta laborantza-paisaiaren bilakaerari dagokionez ere (Narbarte et al., 2019).

\subsection{XVII.-XIX. mendeak: intentsifikazioa}

Zizurkil 1615ean banandu zen Tolosako jurisdikziopetik ${ }^{21}$, eta ordutik udalerri independente gisa garatu izan da. Aro Modernoan zehar, herriko baserri-paisaiak eraldaketa nabarmenak pairatu zituen, tokiko landa-gizarte tradizionala deitu izan dena egituratzearekin batera (Mora, 2006).

Baserri berrien fundazioek aurrera jarraitu zuten XVII., XVIII. eta XIX. mendeetan zehar. Bi bide izan ziren ohikoenak. Alde batetik, zenbait etxeren jabetzak zatitu egin ziren baserri berriak sortzeko. Hala, 9 baserri sortu ziren abereentzako borda izandako guneetan, beste etxe batzuen inguruan (I taula). Etxabesaletxe izan zen goiztiarrena, 1618an jada etxe gisa aipatuta ageri baita ${ }^{22}$; gainerako kasuetan, aldaketa XVII. eta XVIII. mendeetan eman zen ${ }^{23}$. Prozesu honen ondorioz, aurreko fasean egituratutako bizigune-sarea trinkotu egin zen, espazioaren okupazio dentsoago bati bidea irekiz. Beste aldetik, ordura arte abeltzaintzarako zein basogintzarako erabilitako espazio asko laborantzara bilakatu ziren. 8 baserri Eskeltzu mendi inguruan kokatutako sarobeetan eraiki ziren (I taula). Gorago esanda gelditu denez, lehen saiakera 1539an egin zuen Martin Ruiz Donemiliagakoak; kontzejuak egindako salaketaren ondorioz, eraikin batzuk eraitsi eta beste batzuk mantendu egin ziren ${ }^{24}$. Beste 7 baserri, aldiz, herri-lurretako sail txikietan eraiki ziren (I taula), hauek XIX. mende hasieran masiboki pribatizatu ondoren ${ }^{25}$. Baserri berri hauek habitat gero eta sakabanatuago bat eratu zuten, jatorrizko herrigunetik at; haietariko zenbait parrokia-elizatik 4 $\mathrm{km}$ baino gehiagora kokatuta zeuden, ia $500 \mathrm{~m}-\mathrm{ko}$ altitudean (Narbarte, 2020).

Eraikuntza-moldeetan ere aldaketa handiak eman ziren, berreraikitako baserri zaharretan zein baita fundazio berrietan. XVII. mende erdialdetik aurrera, arkitek- tura-eredu barrokoek ordezkatu zituzten aurreko faseko zenbait eraikin: zurezko bilbaduradun baserriak izan ziren tipologiarik ohikoena, karrerapez hornituta (Andrezketa, Aretagoikoa, Aretazpikoa, Nekola) zein gabe (Amabi, Olentzarozahar); beste kasu batzuetan, harri-hormazko egituradun baserriak altxa ziren (Azkarate, Bikarioetxezar, Iraola, Landare). XVIII. mendetik aurrera, berriz, harrizko egitura erregularreko baserri neoklasikoak nagusitu ziren (Agirre, Altxurriaga, Arizkurutzeta, Arritxipi, Astabere, Bidegurutze, Errekalde) ${ }^{26}$.

Gisa berean, jasotako lurzoru-erregistroek ere laborantza-moldeen aldaketa bat islatzen dute fase honetan. Aztertutako lau zundaketek A2 horizonte bat erakusten dute; egungo laborantza-gainazalaren azpian. ZIZ/1 eta ZIZ/4 zundaketetan, A2 horizonte hauek A3, lehen faseko laborantza-horizonteen gainean kokatuta daude, eta potentzia handia dute $(25-50 \mathrm{~cm}) ; \mathrm{ZIZ/2}$ eta ZIZ/5 zundaketetan, berriz, E/B horizonte mineralen gainean kokatzen dira, eta 10-15 cm-ko potentzia baino ez dute. A2 horizonteek eduki organiko handia dute, elementu biofilikoen presentziari lotutako Osagai Nagusien (ON2zı/1, ON1zı/2, ON2zız/4, -ON1zız/5) balio altuek eta elementu litogenikoei lotutakoen (ON1zı/1, ON2zIz/2, ON1zız/4, ON1zı//5) balio baxuek erakusten dutenez. Haatik, gaineko eta azpiko horizonteetatik bereizten dituen ezaugarri nagusia kaltzio (Ca) kontzentrazio handia da; oinarriko balio baxuetatik abiatuta (1000-20.000 cps), $\mathrm{Ca}$ balioak nabarmen hazten dira A2 horizonteetan ( $\geq 100.000 \mathrm{cps}$ ), begiz antzeman daitezkeen kare-arrasto karbonatodunen presentziari loturik $\left(\mathrm{CaO}+\mathrm{H}_{2} \mathrm{O}+-\right.$ $\left.\mathrm{CO}_{2} \rightarrow \mathrm{CaCO}_{3}\right)$. ZIZ/4 zundaketan unitate honetatik jasotako lagin bat datatzeko saiakerak emaitza inkoherentea eman zuen (ikus II taula). Dena den, azpiko (A3) eta gaineko (A1) laborantza-horizonteen kronologiei begira, ondoriozta liteke XVII. mende bukaeratik XX. mende erdira doala A2 horizontearen deposizioa, eta beraz denbora-tarte horretan nagusitu zirela kare-adizioak ohiko laborantza-praktika gisa. Kronologia horrek bat egiten du, hain zuzen ere, inguruko beste eskualde batzuetan dokumentatu diren antzeko fenomenoekin (Narbarte-Hernández et al., 2019).

\footnotetext{
${ }^{21}$ Simancasko Artxibo Orokorra, Tesoro, 287:48.

22 "La casa de Salechea de Echave"; Valladolideko Erret Kantzelaritzaren Artxiboa, C 3150/1. Orotariko Euskal Hiztegiaren arabera, sa(ra)letxe hitza "ardientzako bazka gordetzen duten lekua" da. Saletxe izena duten etxe ugari jasotzen ditu, Ataunen, Arinek (1927), XVII. eta XIX. mendeen artean eraikiak. Izen bereko baserri gehiago ere topatzen dira, Ezkion kasu (2020/05/25): b5m.gipuzkoa.eus/web5000/kaletegia/ezkio/ezkio_barreiatua/024. ${ }^{23}$ Mugiroberri 1623an aipatzen da "borda o casa de ganado" gisa, baina 1708rako baserria zen jada. Legargain "casa de ganado" gisa aipatzen da 1694an, eta baserria zen 1726an. Malkorra "casilla de ganados" gisa aipatzen da 1615an, eta 1747an bihurtu zuten baserri. Abeletxe baserriaren jatorria 1717an aipatutako "borda de ganado" bat litzateke, 1761etik aurrera baserri bihurtua eta errentan emana. Etxetxo, berriz, 1750ean aipatzen da "Echecho azesoria" gisa; espainieraren Erret Akademiaren hiztegiak honako adiera jasotzen du accesoria hitzarentzat: "Edificio contiguo a otro principal y dependiente de este".

${ }^{24}$ Pagamendi eta Arizkurutzeta, bereziki. Baserri hauen inguruko gatazkak berriro gertatu ziren 1698-1703 artean (Valladolideko Erret Kantzelaritzaren Artxiboa, C3150/1) eta 1725ean (Gipuzkoako Artxibo Orokorra, COCRI/143/6). Kasu berezi bat Itzumitz baserria izan zen, udalak eraiki baitzuen, eta errentan eman.

${ }^{25}$ Pribatizaziorik handiena 1808 eta 1814 artean gertatu zen, Frantsesteak udal erakundeei eragindako zorrak kitatzeko. Gipuzkoako Batzar Orokorrek eskatuta, 1817an udal bakoitzak saldutako eta kontserbatutako herri-ondasunen zerrenda osatu zuen, eta bertan azter daiteke Andatza mendiko lurren pribatizazioa. GAO, JDIM, 1/17/80.

${ }^{26}$ Erreferentziazko adibide bat izan daiteke Olaberriako Otsoategi baserria (Mendizabal, 2014). Tipologia barrokoen ikuspegi orokor baterako, ikus Santana et al. (2001).
} 
Zizurkilgo lurzoruen ezaugarriak eta aztertutako erregistroen osaera kontutan atxikirik, kare-arrasto horiek ezin daitezke adizio antropogeniko bat bezala baino uler. Praktika hau aski ezaguna da Euskal Herriko isurialde atlantiarrean, Aro Modernoan artoa bezalako produktu amerikarrak sartu ondoren nagusitu zen biurteko errotazio-sistema berriaren osagai gisa, artoaren iraultza izenaz ezagutzen denaren testuinguruan (Bilbao \& Fernández de Pinedo, 1984; Aragón, 2015). Horren arabera, landetan garia, artoa eta arbia lugorririk gabe txandakatzen ziren, bi urteko ziklo intentsiboetan; etxeen inguruko baratzetan, aldiz, polilaborantza intentsibo bat gauzatzen zen, azak, porruak, tipulak eta bestelako barazkiak landuz ${ }^{27}$. Laborantza-erritmo intentsibo horiei eusteko, ezinbestekoa zen ongarri organikoak (simaurra) gehitzea, eta honek eragindako azidifikazioari aurre egiteko baliatzen zen karea (Narbarte et al., 2021). Funtsean, beraz, aztertutako A2 horizonteek laborantza-ekoizpenaren intentsifikazio bat islatzen dute, hots, lur-unitateko etekin handiagoa lortzera bideratutako eredu agronomiko baten garapena. Karearen ekoizpenak baserrien ekonomiarako hartu zuen garrantziaren lekuko, Zizurkileko paisaian sakabanatuta hainbat karobiren arrastoak ikus daitezke.

Intentsifikazio-prozesu horren baitan sartzen dira, halaber, higadura gutxitu eta etekinak handitzera bideratutako inbertsioak; zundatutako soroetan ikus daitezkeen egokitzapen topografikoak eta hidrografikoak, kasu. ZIZ/2 zundaketaren kasuan, adibidez, Aretagoikoa eta Aretazpikoa baserrien arteko baratzea euste-hormaz mugatuta dago, eta horiek arras gutxitu ahal izan dute higadura, erregistroen kontserbazioa erraztuz. Izan ere, baratzearen kota inguruko soroena baino ia metro bete altuagoa da. Antzeko zerbait gertatzen da ZIZ/5 zundaketaren kasuan; Donemiliaga dorretxearen inguruko soroak euste hormaz eta drenaia-kanalez egokitutako terraza zabal bat osatzen du, eta horri esker kontserbatu ahal izan da lurzoru-erregistroa. ZIZ/4 zundaketaren kasuan bereziki; Kamioaundi, Plazaetxeberri eta Mutio baserrien artean dagoen dolina zabala bi terraza mailakatutan antolatuta dago, drenaia luzetarako kanal baten bidez ziurtatzen delarik.

Fase honetan garatu zen, laburbilduz, XX. mendera arte iraungo zuen baserriko laborantza-eredu "tradizionala". Haren ezaugarri nagusiak izan ziren etxeen eta ustiategien dispertsioa, aldez aurretik kolonizatu gabeko espazioetara hedatuz eta maizterren kopurua ugarituz; jatorri amerikarreko produktuen sarrera eta horiei lotutako errotazio-ziklo intentsiboagoen garapena, ongarritze- eta kareztatze-praktikei zein egokitzapen topografiko eta hidrografikoei loturik; prozesu produktiboen atomizazio gero eta handiago bat etxe-unitatean zentratuta; eta arkitektura-ereduen berrikuntza bat, behar produktibo berriei egokituta.

\subsection{XX.-XXI. mendeak: gainbehera}

XIX. mendeaz geroztik, erregimen liberalaren ezarpenak eta Industria Iraultzak bete-betean jo zuten Gipuzkoa, eta Zizurkilen ere aldaketa soziologiko zein urbanistiko nabarmenak gertatu ziren (Zapirain, 2007). Hauek tokiko baserri-paisaiari eragin zioten, aurreko garaietan kodifikatutako eredu tradizionalaren gainbehera abiatuz.

Lehenik eta behin, baserrien dispertsiorako joera gelditu, eta neurri batean atzera ere egin zuen. XIX. mendean pribatizatu ziren herri-lurretan eraikitako baserri askok, adibidez, bizitza laburra izan zuten, XX. mende hastapenerako abandonatu egin baitziren gehienak ${ }^{28}$. Haien kokapen guztiz periferikoak, komunikazio txarrek eta lurren kalitate eskasak —altitudeagatik zein erliebe malkarragatik - maizter pobreak bakarrik erakarri ahal izan zituen; horiek izan ziren, hain zuzen ere, industrializazioak erakarri zituen lehen langileak. Industria-guneak eta haiei lotutako hirigune berriak, berriz, udal barrutiaren beste muturrean garatu ziren, Asteasuerrekak Oriarekin bat egiten duen inguruan, bereziki 1911ean sortutako Papelera del Oria lantegiari loturik (Tuduri, 2011). Prozesu honen ondorioz, inguruko baserri gehienak hormigoizko eraikin berriekin ordezkatu ziren.

Bigarrenik, laborantza-eredua bera errotik aldatu zen. Aztertutako lau lurzoru-erregistroetan, kare-pinportaz aberastutako A2 horizonteen gainean, 10 eta $40 \mathrm{~cm}$ bitarteko sakonera duen A1 horizonte bana agertzen da, eta honen gainean $10 \mathrm{~cm}$ inguruko $\mathrm{O}$ horizonte organikoa, egungo gainazalari dagokiona. Horizonte hauen ezaugarri nagusia elementu litogenikoen kontzentrazioak (ON1zız/1; ON2zız/2; ON1zız/4; ON1zız/5) gutxitzea eta osagai organikoa (ON2zIz/1; ON1zız/2; ON2zII/4; ON4zIz/5) nabarmen emendatzea da. Haatik, Ca kontzentrazioak nabarmen egiten du atzera A2 horizonteekiko, oinarrizko sedimentuen mailetara itzuliz; hots, gizakiak egindako kare-adizioen eragina desagertuta, elementu honen presentzia anekdotiko bilakatzen da atzera, lurzoruon osaeran. Kareztatzea XX. mendearen lehen erdian zehar abandonatu zela kontutan atxikirik, garai hori jo behar da horizonte hauen garapenaren abiapuntuko datatzat.

$\mathrm{P}, \mathrm{Zn}, \mathrm{S}$ edota $\mathrm{Pb}$ bezalako elementuen kontzentrazio handiak bi faktorek azal litzakete. Alde batetik, lurzoruaren gainazalean materia organiko deskonposatu gabea ugariagoa izateagatik (Puget \& Lal, 2005, Lou et al., 2012; Yamashita et al., 2006); bestetik, laborantza intentsiboago baten ondorioz, fosfatoak bezalako ongarri industrialak gehituta (Rodríguez et al., 2006; Huang \& Jin, 2008; Atafar et al., 2010; Zhang et al., 2012).

Izan ere, aurreko fasean garatutako errotazioa bertan behera gelditu zen XX. mendean zehar. Landa-populazioen zati handi bat industria-sektorerantz lerratzen ari zelarik, Gipuzkoako Foru Aldundiak modelo-landetxe

\footnotetext{
${ }^{27}$ Zizurkilgo Udal Artxiboa, 1/1/5.

${ }^{28}$ Ikus Moraza (2010).
} 
eta eskola bat sortu zuen Zizurkilgo Fraisoro baserrian, lurraldeko laborantzaren teknifikazioa sustatzeko ${ }^{29}$. Ondorioz, autokontsumorako laborantza desagertu eta espezializaziorako joera indartu zen, ekoizpena tokiko komunitatetik at zeuden merkatu-fluxuen menpe kokatuz. Aireko argazkien segidak erakusten duenez, gari- eta artasoroak ia osoki ordezkatu dira abereak elikatzeko belardiekin (8 irudia), inguruko merkatu urbanoen eskariei erantzuteko esnegintza-sektorea garatzen joan den neurrian.

Aldaketa hauek guztiek errotik itxuraldatu dute $\mathrm{Zi}$ zurkilgo paisaia, baita herritarrek hartaz duten irudia ere. Baserriari lotutako laborantza-eredu tradizionala birtualki desagertuta dago, eta haren ordez merkatura bideratutako ekoizpen espezializatuak nagusitu dira, han-hemen, etxeen inguruan, autokontsumorako eta aisialdirako jarduera gisa lantzen diren baratze-sail txikiekin osatuta. Behin beren funtzionaltasun produktiboa galduta, baserri asko eraberritu egin dira, landa-giroko etxebizitza bihurtzeko. Era berean, azken hamarkadetan eraiki diren azpiegitura-sare berriek ere haustura bisuala eragin dute Zizurkilgo paisaian; AHTren Euskal Y sareak, adibidez, udal barrutia zeharkatzen du, Adunibar, Alkanitz edota Salugarate baserrietatik metro gutxira igarota (Pérez \& Bueno, 2004; Ajamil, 2017).

\section{ONDORIOAK}

Iturri dokumentalen, ahozkoen, arkitektura-elementuen zein lurzoruen azterketa estratigrafikoa uztartuta, Zizurkilen garatutako ikerketa arkeologikoak baserri-paisaiaren bilakaera berreraikitzeko bidea ireki du, Erdi Aroaren bukaeratik XXI. mendera. Metodo arkeologikoak fase hauek paisaian utzitako arrasto material desberdinak identifikatzeko eta deskodifikatzeko aukera eskaintzen du, egitura edo artefaktu soiletik harago doazen zeharkako ikuspegiak zabalduz. Lortutako emaitzek erakusten dutenez, tokiko paisaia etengabeko bilakaeran dago, ingurugiro-faktoreek zein giza jarduerek, eta bereziki laborantzak, moldatua. Bilakaera honetan hiru fase bereiz daitezke: 1) baserri-paisaiaren lehen kodifikazioa XIV. eta XVI. mendeen artean; 2) XVII.-XIX. mendeen artean jatorri amerikarreko espezieen sarrerak, "artoaren iraultza" delakoak, eragindako intentsifikazio-prozesua; eta 3) XX. mendeaz geroztiko gainbehera, industria iraultza indartzearekin batera. Zentzu zabalago batean, Zizurkilgo kasuak agerian uzten du gisa honetako paisaia kulturalen izaera konplexua eta dinamikoa, landa-komunitateen historia ikertzerakoan azalpen monokausalak gainditzeko beharra azpimarratuz eta haien baitako harreman sozial eta ekologikoen epe luzeko azterketa transdisziplinarren beharra nabarmenduz.
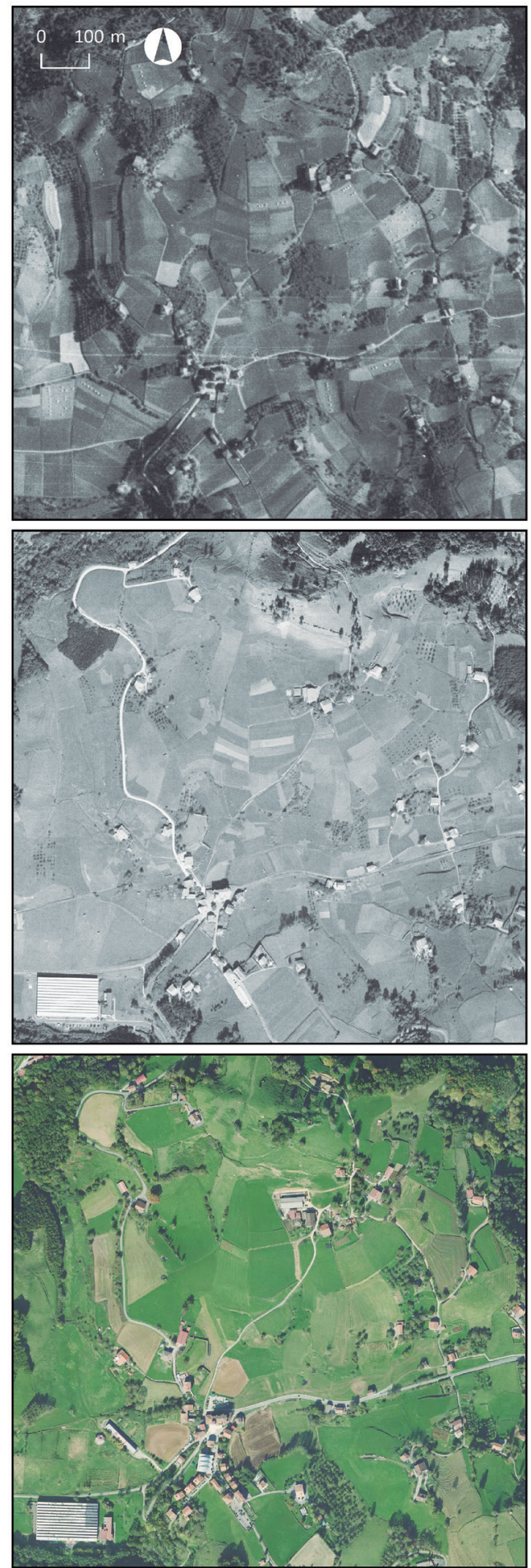

Irudia 8: Zizurkilgo baserri-paisaia: polilaborantza tradizionaletik belardi-espezializaziora XX. mendearen bigarren erdian. (a) 1945-1946. (b) 1984. (c) 2019. Iturria: GeoEuskadi./ Rural landscape in Zizurkil: from traditional polyculture to grassland specialisation over the second half of the $20^{\text {th }}$ century. (a) 1945-1946. (b) 1984. (c) 2019. Source: GeoEuskadi.

\footnotetext{
${ }^{29}$ Hondarribiko Udal Artxiboa, B.1.II.1.14. XX. mende hasieratik, zentroak ongarri kimikoak kostu-salneurrian eskaini zizkien Gipuzkoako baserritarrei, eta lehiaketak ere antolatu zituen hobekuntza teknikoak saritzeko. Fraisoroko eskola zein ingurumen- eta nekazal laborategia aktibo daude oraindik ere, Gipuzkoako Foru Aldundiaren menpe: https://www.gipuzkoa.eus/eu/web/fraisoro (kontsulta: 2021/05/20).
} 


\section{AITORTZA}

Ikerketa hau Gipuzkoako Foru Aldundiak eta Eusko Jaurlaritzak lagunduta dute, Ondarearen eta Paisaia Kulturalen inguruko Ikerketa Taldearen (EJ, IT931-16) baitan. Egileok eskerrak eman nahi dizkiegu Ainhoa Azpeitiari eta Joxin Azkueri, emandako laguntzagatik; baita Zizurkilgo herritarrei ere, egindako harreragatik eta erakutsitako interesagatik.

\section{ERREFERENTZIAK}

Agirre Badiola, D., 1912. Garoa. Florentino Elosu, Durango.

Agirre Mauleon, J., 2005. Anoetako baserriak. Aranzadi Zientzia Elkartea, Donostia.

Ainz Ibarrondo, M.J., 2001. El caserío vasco en el país de las industrias. Nekazaritza, Arrantza eta Elikadura Ministerioa, Madril.

Ajamil Baños, J., 2017. Zizurkil-Aduna-Andoain zatia (Gipuzkoa). Arkeoikuska 16, 439-440.

Aragón, Á., 2015. El sector agrario guipuzcoano en la encrucijada de los siglos XVI y XVII. Lurralde 38, 89-116.

Arin, J., 1927. Establecimientos humanos y zonas pastoriles: pueblo de Ataun. Anuario de Eusko Folklore 7, 1-26.

Aston, M., Gerrad, C., 2013. Interpreting the English Village: Landscape and community at Shapwick, Somerset. Oxbow Books, Oxford.

Atafar, Z., Mesdaghinia, A., Nouri, J., Homaee, M., Yunesian, M., Ahmadimoghaddam, M., Mahvi, A.H., 2010. Effect of fertilizer application on soil heavy metal concentration. Environmental Monitoring Assessment 160, 83-89.

Barandiaran, J.M., 1961. Bosquejo etnográfico de Sara, II. La población y el sistema de poblamiento. Anuario de Eusko Folklore 18,107-180.

Barandiaran, J.M., 1962. Bosquejo etnográfico de Sara, III. Los establecimientos humanos y la casa rural. Anuario de Eusko Folklore 19, 47-123.

Bilbao, L.M., Fernández de Pinedo, E., 1984. La producción agraria en el País Vasco peninsular, 1537-1850. Vasconia 2, 83-198.

Campos, T., 2020. Los caseríos en el País Vasco: conocimiento histórico y gestión. Una herramienta para la educación y socialización del patrimonio. En: Grau-Sologestoa, I., Quirós-Castillo (eds.), Arqueología de la Edad Moderna en el País Vasco y su entorno, 71-85. Archaeopress, Oxford.

Caro Baroja, J., 1944. La vida rural en Vera de Bidasoa (Navarra). CSIC, Madril.

Caro Baroja, J., 1969a. Las bases históricas de una economía 'tradicional'. Cuadernos de Etnología y Etnografía de Navarra 1(1), 7-33.

Caro Baroja, J., 1969b. Sobre la casa, su 'estructura' y sus 'funciones'. Cuadernos de Etnología y Etnografía de Navarra 1(1), 35-66.

Douglass, W., 1975. Echalar and Murelaga: opportunity and rural exodus in two Spanish Basque villages. C. Hurst \& Co. Publishers Ltd., Londres.

Duvert, M., 2012. Pour une histoire de la charpenterie Basque: l'apport du Labourd. Kobie Antropología Cultural 16, 181-206.
Elizanburu, J.B., 1855-1867. Ikhusten duzu goizean. Armiarma (2019-02-13). Erabilgarria: https://klasikoak.armiarma.eus/ idazlanak/E/ElizanburuJBKoplak004.htm

Galdos, M., 2015. Kolonialismoaren arkeologia: Gipuzkoako dolaredun baserrien agerpena XVI. mendean. Gradu Amaierako Lana (EHU).

Gereñu, M., 2011. XVI., XVII. eta XVIII. mendeetako arkeologia Gipuzkoan. Gipuzkoako Foru Aldundia, Donostia.

Giralt, S., Moreno, A., Bao, R., Sáez, A., Prego, R., Valero, B.L., Pueyo, J.J., González-Sampériz, P., Taberner, C., 2008. A statistical approach to disentangle environmental forcings in a lacustrine record: the Lago Chungará case (Chilean Altiplano). Journal of Paleolimnology 46(3), 487-502.

Giralt, S., Rico-Herrero, M.T., Vega, J.C., Valero-Garcés, B.L., 2011. Quantitative climate reconstruction linking meteorological, limnological and XRF core scanner datasets: the Lake Sanabria case study, NW Spain. Journal of Paleolimnology 40(1), 195-215.

Greenwood, D., 1976. Unrewarding Wealth: The Commercialization and Collapse of Agriculture in a Spanish Basque Town. Cambridge University Press, Cambridge.

Hoskins, W.G., 1954. The Making of the English Landscape. Hodder \& Stoughton, Londres.

Hotelling, H., 1933. Analysis of a complex of statistical variables into principal components. Journal of Educational Psychology $24,417-441$

Huang, S.-W., Jin, J.Y., 2008. Status of heavy metals in agricultural soils affected by different patterns of land use. Environmental Monitoring Assessment 139, 17-327.

Ibáñez, Á., Agirre Mauleon, J., 1998. Arquitectura rural en madera en el siglo XVI en el área de Tolosaldea. Los "caseríos-lagar" de Etxeberri (Gaztelu) y Etxenagusia (Eldua). Zainak 17, 67-83.

Kirchner, H., 2010. Por una arqueología agraria. Perspectivas de investigación sobre espacios de cultivo en las sociedades medievales hispánicas. Archaeopress, Oxford.

Larramendi, M., 1882. Corografía ó descripción general de la Muy Noble y Muy Leal Provincia de Guipúzcoa. Subirana, Bartzelona.

Lema, J.A., Tapia, I., 1995. Colección Diplomática del Archivo Municipal de Tolosa. Tomo II (1420-1499). Eusko Ikaskuntza, Donostia. Fuentes Documentales Medievales del País Vasco, 65.

Lhande, P., 1914. Mirentchu. Plon-Nourrit, Paris.

Loti, P., 1897. Ramuntcho. Calmann-Lévy, Paris.

Margalef, O., Martínez Cortizas, A., Kylander, M., Pla-Rabes, S., Cañellas-Boltà, N., Pueyo, J.J., Sáez, A., Valero-Garcés, B.L., Giralt, S., 2014. Environmental processes in Rano Aroi (Easter Island) peat geochemistry forced by climate variability during the last 70 kyr. Palaeogeography, Palaeoclimatology, Palaeoecology 414, 438-450.

Martínez Diez, G., 1975. Guipúzcoa en los albores de su historia. Gipuzkoako Aldundia, Donostia.

Mendizabal Sandonís, O., 2014. Arkitekturaren arkeologia: Otsoategi baserria. Gradu Amaierako Lana (EHU).

Mora, J.C., 2005. Zizurkilgo historia bailaratik hiribildura (11861615). Aranzadi Zientzia Elkartea, Donostia.

Mora, J.C., 2006. Gizarte tradizionala Zizurkilen (1615 - 1800). Aranzadi Zientzia Elkartea, Donostia. 
Moraza, A., 2010. Zizurkilgo baserriak. Aranzadi Zientzia Elkartea, Donostia.

Moreno, D., 1990. Dal documento al terreno. Storia e archeologia dei sistemi agro-silvo-pastorali. II Mulino-Ricerche, Bolonia.

Narbarte-Hernández, J., 2020. Late Medieval and Modern Settlement Dynamics in Three Atlantic Basque Villages: An Approach on the Rural Landscape. In: Grau-Sologestoa, I., Quirós-Castillo, J.A. (eds.), Arqueología de la Edad Moderna en el País Vasco y su entorno, 103-120. Archaeopress, Oxford.

Narbarte-Hernández, J., Iriarte, E., Rad, C., Carrancho-Alonso, Á., González-Sampériz, P., Peña-Chocarro, L., Quirós-CastiIlo, J.A., 2019. On the origin of rural landscapes: looking for physico-chemical fingerprint of historical agricultural practice in the Atlantic Basque Country (N Spain). Science of the Total Environment 681, 66-81.

Narbarte-Hernández, J., Iriarte, E., Carrancho-Alonso, Á., Olazabal-Uzkudun, A., Rad, C., Arriolabengoa, M., Aranburu, A., Quirós-Castillo, J.A., 2021. Geochemical fingerprint of agricultural liming as a regular management practice in Modern-period Basque farming. Science of the Total Environment 787, 147525 .

Narbarte-Hernández J., Iriarte E., Rad C., Tejerizo C., Fernández Eraso J., Quirós-Castillo J.A., 2020. Long-term construction of vineyard landscapes: the deserted village of Torrentejo (Basque Country, Spain). Catena 187, 104417.

Pérez Vicente, D., Bueno Moreno, M., 2004. Vitoria-Gasteiz-Bilbao-Donostia-San Sebastián Abiadura Handiko Burdinbidea. Atala: Zizurkil-Urnieta. Arkeoikuska 03, 437-439.

Rodríguez Martín, J.A., López Arias, M., Grau Corbí, J.M., 2006. Heavy metals contents in agricultural topsoils in the Ebro basin (Spain). Application of the multivariate geoestatistical methods to study spatial variations. Environmental Pollution $144,1001-1012$

Roldán, J.M., 1991. Fuentes Documentales Medievales del País Vasco \#036. Colección Diplomática del Archivo Municipal de Tolosa. Tomo I (1256-1407). Eusko Ikaskuntza, Donostia.

Russell, E.W.B., 1997. People and the Land through Time. Linking Ecology and History. New Yale University Press, Haven.
Santana, A., Larrañaga, J.Á., Loinaz, J.L., Zulueta, A. (ed.), 2001. Euskal Herriko baserriaren arkitektura. Euskal Herriko Unibertsitatea, Bilbo.

Santana, A., Izagirre, M., Sagarzazu, I., Ibáñez, M., Torrecilla, M.J., Zabala, M., Ayerza, R., Cano, M., Studer, G., Tellabide, J., 2003. Igartubeiti: Gipuzkoako baserri bat. Ikerketa, zaharberrikuntza, zabalkundea. Gipuzkoako Foru Aldundia, Donostia.

Stagno, A.M., 2018. Gli spazi dell'archeologia rurale. Risorse ambientali e insediamenti nell'Appennino ligure tra XV e XX secolo. All'Insegna del Giglio, Firenze.

Susperregui, J., Telleria, I., Urteaga, M.M., Jansma, E., 2017. The Basque farmsteads of Zelaa and Maizgoena: New dendrochronology-based findings about the evolution of the built heritage in the northern Iberian Peninsula. Journal of Archaeological Science. Reports 11, 695-708.

Telleria, I., Susperregui, J., Urteaga, M., 2020. Estudio sobre el origen del caserío vasco mediante el análisis de estructuras medievales en madera. En: Grau-Sologestoa, I., Quirós-CastiIlo (eds.), Arqueología de la Edad Moderna en el País Vasco y su entorno, 86-102. Archaeopress, Oxford.

Truchuelo, S., 1997. La representación de las corporaciones locales guipuzcoanas en el entramado político provincial (siglos XVI-XVII). Gipuzkoako Foru Aldundia, Donostia.

Tuduri Esnal, F., 2011. Papelera del Oria, una fábrica centenaria (1911-2011). Papelera del Oria, Zizurkil.

USDA, 2014. Keys to soil taxonomy. United States Department of Agriculture, Washington DC.

Zapirain, D., 2007. Zizurkil: Aldaketa haizeak (1800-1950). Aranzadi Zientzia Elkartea, Donostia.

Zhang, F., Li, Y., Yang, M., Li, W., 2012. Content of heavy metals in animal feeds and manures from farms of different scales in Northeast China. International Journal of Environmental Research and Public Health 9, 2658-2668. 